\title{
Exploring brand management strategies in Chinese manufacturing industry
}

\author{
Fenfang Lin $^{1} \oplus \cdot$ Wai-Sum Siu ${ }^{2}$
}

Revised: 5 October 2018 / Published online: 1 August 2019

(c) The Author(s) 2019

\begin{abstract}
The purpose of this paper was to empirically explore how Chinese private manufacturers make strategic branding decisions. We develop a conceptual framework to investigate the branding decisions undertaken by Chinese manufacturers. Interview data were subjected to qualitative thematic analysis and quantitative categorical principal component analysis. Data reveal a branding schema that illustrate four types of B2B brander: achievement competencies branders, awareness competencies branders, novice competencies branders, and no-competencies branders. The schema describes the trajectory of the progressive evolution of B2B branders. This paper contributes to the long-called-for formation of a theoretical framework of $\mathrm{B} 2 \mathrm{~B}$ branding from the amorphous literature and provides a direction for manufacturers to undertake branding practice. The exploratory nature lays foundations for further research to investigate B2B branding in other contexts.
\end{abstract}

Keywords B2B branding $\cdot$ Brand management $\cdot$ Branding impediments $\cdot$ Branding strategies

\section{Introduction}

It is well established that a powerful brand acts as an antidote to potential risks of products or services that fail to deliver their underlying functional benefits (Knox 2004; Viardot 2017). In consumer markets, brands help sellers to achieve a competitive edge by adding value to products and services (Sheth and Sinha 2015; Gomes et al. 2016). Recently, branding in the business-to-business (B2B) realm has developed substantially with a number of brands gaining increased recognition in the marketplace, such as IBM, UPS, Siemens, Intel and Lenovo (Knox 2004; Interbrand 2016). The new B2B branding research stream illustrates how a well-established brand can help B2B firms to create sustainable business relationships with buyers (Ghosh and John 2009; Marquardt 2013) and to maximise benefits

Fenfang Lin

Fenfang.Lin@ @oton.ac.uk

Wai-Sum Siu

wssiu@hkbu.edu.hk

1 Room: 2/4045, Southampton Business School, Highfield Campus, University of Southampton, Southampton SO17 1BJ, UK

2 Department of Marketing, Hong Kong Baptist University, Kowloon Tong, Kowloon, Hong Kong derived from raising industrial barriers against competition, thus achieving financial returns (Michell et al. 2001; Ohnemus 2009; Anees-ur-Rehman et al. 2018).

Although B2B branding research has emerged as an independent discipline, it has also attracted controversies (Seyedghorban et al. 2016). First, branding itself is not rooted in a theory but is formed by paradigmatic examples (Kay 2006), insofar as it contributes to an inadequate and amorphous body of B2B branding literature (Leek and Christodoulides 2011; Gomes et al. 2016). Without an overarching theory to define the field of knowledge, the development of B2B branding research has to incorporate other domains (Seyedghorban et al. 2016), such as cognitive psychology theory (Keller 1993; Lin et al. 2019), social exchange theory (Nyadzayo et al. 2011), information economics theory (Homburg et al. 2010), and resource-advantage theory (Marquardt 2013). In the face of such a range of theories, marketing researchers advocate a need to explore the development of a relatively independent knowledge construct for B2B brand management (Seyedghorban et al. 2016; Cassia et al. 2017).

Second, there are evident gaps in the B2B branding studies from emerging markets (Seyedghorban et al. 2016). Existing studies have covered emerging economies in India (Nyadzayoa et al. 2018), Russia (Tarnovskaya and Biedenbach 2016), Taiwan (Chen et al. 2011) and Latin America 
(Sheth and Sinha 2015), but to date, not many studies have focused on mainland China-the largest B2B market that has the most significant growth opportunities (B2B International 2016). The Chinese research context has rich intellectual and cultural traditions with vibrant economic growth, offering unique marketing and branding phenomena and idea, and in turn, it has immense potentials to contribute to universal theories by modifying, enriching, and supplementing Western marketing and branding concepts/ theories, and offering new paradigms and tentative models. Given that management researchers tend to employ the lens of advanced markets to examine events in emerging markets, Tsui (2007) argues the need to develop theoretical innovations through contextualised theory building and encourages further research on Eastern-specific contexts (Sheth 2011; Barkema et al. 2015).

Against this backdrop, the objective of this research is to explore how Chinese industrial manufacturers undertake their strategic branding decisions. By reviewing the amorphous literature body of B2B branding, we distil four most relevant $\mathrm{B} 2 \mathrm{~B}$ branding dimensions, namely brand orientation, brand impediments, brand architecture and brand communication, to investigate their applications in the Chinese manufacturing context. Considering there is limited research available to explain the B2B branding phenomenon in emerging markets (Leek and Christodoulides 2011; Sheth and Sinha 2015), this exploratory study adopts qualitative interview method to illustrate the unique features of an emerging market with unbranded competition and scarce resources in a depth (Sheth 2011). As our main contribution, we answer calls to extend knowledge on Eastern-specific branding research (Wang et al. 2017). We contribute to prior literature through advancing the knowledge body of B2B branding with our tentative framework. Based on a smallscale exploratory investigation, our research further refines the framework into a tentative contextual schema and lays a foundation for future studies on B2B branding in emerging markets, particularly for Chinese firms.

A review of the literature on brand management follows below. We then illustrate the methodological approach we adopt and reveal the findings, followed by discussions, implications, limitations and future research directions.

\section{Literature review}

\section{An overview of brand and B2B brand management}

Despite great endeavours to outline a consensual definition of a brand, numerous explanations exist in marketing research literature (de Chernatony and Riley 1998; Mitchell et al. 2012). A brand is often interpreted as a name, logo, or trademark to be differentiated from other competitors (Louro and Cunha 2001); or it is deemed as a strategic tool to build industrial barriers in the competition (Anees-ur-Rehman et al. 2018). Overseeing the branding literature, the different ways in which a brand is understood can be viewed in three perspectives: the evolutionary perspective, the competitive perspective and the managerial perspective.

The evolutionary perspective considers the multifaceted nature of a brand is channelled via an evolution from a functional stance to a value-added level (de Chernatony 2009). A brand's functional stance is equivalent to the product paradigm level and serves the purpose of differentiation and positioning by focusing on brand identifiers (Louro and Cunha 2001). The competitive perspective regards 'brand' as a unique competitive advantage positively affects the perceived quality of products and services in both business-toconsumer (B2C) and business-to-business (B2B) markets (Cretu and Brodie 2007; Aaker 1991; Lee et al. 2017). The managerial perspective of a brand originally emerged from consumer markets (Bendixen et al. 2004). A few studies have attempted to relocate consumer-based branding theories to the B2B context, such as applying the Aaker brand equity model and Keller's customer-based brand equity (CBBE) model in B2B contexts (e.g., Kuhn et al. 2008; Biedenbach and Marell 2010; Viardot 2017).

The above three perspectives lay the foundation of understanding the various interpretations of a brand. In the B2B context, the evolutionary perspective of a brand provides an explanation for the evolvement of B2B brand value; the competitive perspective illustrates the competitiveness of a brand and branding benefits perceived by stakeholders; and the managerial perspective provides implications of branding practice. To continue evolving the brand management stream, Glynn (2012) posts that is vital to consider the unique features of B2B markets. B2B branding differs from B2C branding in various aspects (Österle et al. 2018). B2B branding practice is more complex and emphasises building a long-term partnership (Glynn 2012). There are fewer organisational buyers in the B2B sector, which forms a high concentration of buying power for large- and great-value transactions (Kotler and Pfoertsch 2006). The B2B purchase process goes through a buying centre and consists of a group of individuals with various needs and demands (Gomes et al. 2016). They communicate through different channels to sustain continuous buying behaviour (e.g. Yanamandram and White 2006; Keranen et al. 2012). Moreover, B2B branding concerns a corporate level rather than products or services (Simoes et al. 2015), and the most common branding value of emotional and psychology development in the consumer market is less relevant and applicable to a B2B context (Keranen et al. 2012).

To build a strong industrial brand, recent reviews in B2B branding (Leek and Christodoulides 2011; Glynn 2012; Seyedghorban et al. 2016) state a few strategic aspects to 
consider. First, a firm should take brand orientation approach by prioritising branding and incorporate branding in their business strategy development (Zhang et al. 2016). Second, firms should acknowledge the nature of industrial markets that involves a large body of industrial buyers and a prolonged purchasing process (Seyedghorban et al. 2016). These industrial characteristics that form the complexities and difficulties in branding are often interpreted as impediments (Leek and Christodoulides 2012). Third, a firm should adopt an appropriate branding architecture strategy over a choice of corporate branding, product branding or a mixed branding strategy (Keller and Kotler 2012; Gomes et al. 2016); and employ the most effective and efficient communication channels to deliver branding messages (Buil et al. 2013; Karjaluoto et al. 2015). These aspects form four dimensions in B2B branding: Brand Orientation (BO), Brand Impediments (BI), Brand Architecture (BA) and Brand Communication (BC).

\section{The dimensions of B2B brand management}

The four preliminary domains (brand orientation, brand impediments, brand architecture and brand communication) interact with and influence each other to form key aspects of B2B brand management. We outline a B2B brand management framework (see Fig. 1) to lay a theoretical foundation for our empirical study.

\section{B2B brand orientation}

Brand orientation is defined as 'an approach in which the processes of the organisation revolve around the creation, development and protection of brand identity in an on-going interaction with target customers with the aim of achieving lasting competitive advantages in the form of brands'
(Urde 1999, p. 117). The concept of brand orientation has been applied in different fields (Anees-ur-Rehman et al. 2016), including non-profit and public sectors (Ewing and Napoli 2005; Evans et al. 2012; Gromark and Melin 2013), retail industries (Bridson and Evans 2004), service industries (King et al. 2013), corporate levels (Balmer 2013), and small- and medium-enterprises (SMEs) in B2B sectors (Hirvonen et al. 2016). Baumgarth (2010) claimed that brand orientation is an accumulated result based on the internal brand awareness and the external brand image stored in customers' minds. Internally, it incorporates a firm's vision, mission and values and strategically guides a firm's marketing activities (Burmann and König 2011; Urde et al. 2013). Externally, brand orientation is an extension of market orientation as a source to build a sustainable competitive advantage (Hirvonen et al. 2016).

Prior literature indicates that firms are exposed to different levels of strategic brand orientation (Mitchell et al. 2015). Wong and Merrilees (2005) revealed three levels of brand orientation: minimalist, embryonic and integrated. A low level of brand orientation refers to brands as subsidiaries of firms, representing minimalist branding activities and short-term centralisation. An embryonic level of brand orientation consists of progressive marketing activities; and a brand-centric level integrates the brand with marketing activities (Mitchell et al. 2015). Overall, a brand-oriented approach positively affects a firm's branding, marketing and economic performances (Baumgarth 2010). Nevertheless, the existing studies on SME brand orientation lack a theoretical foundation to accommodate the empirical development (Baumgarth 2010; Huang and Tsai 2013). The application of brand orientation in the B2B market is not fully explored, and there is limited evidence to support how the level of brand orientation affects a firm's brand performance in the B2B market.
Fig. 1 The analytical framework of B2B brand management

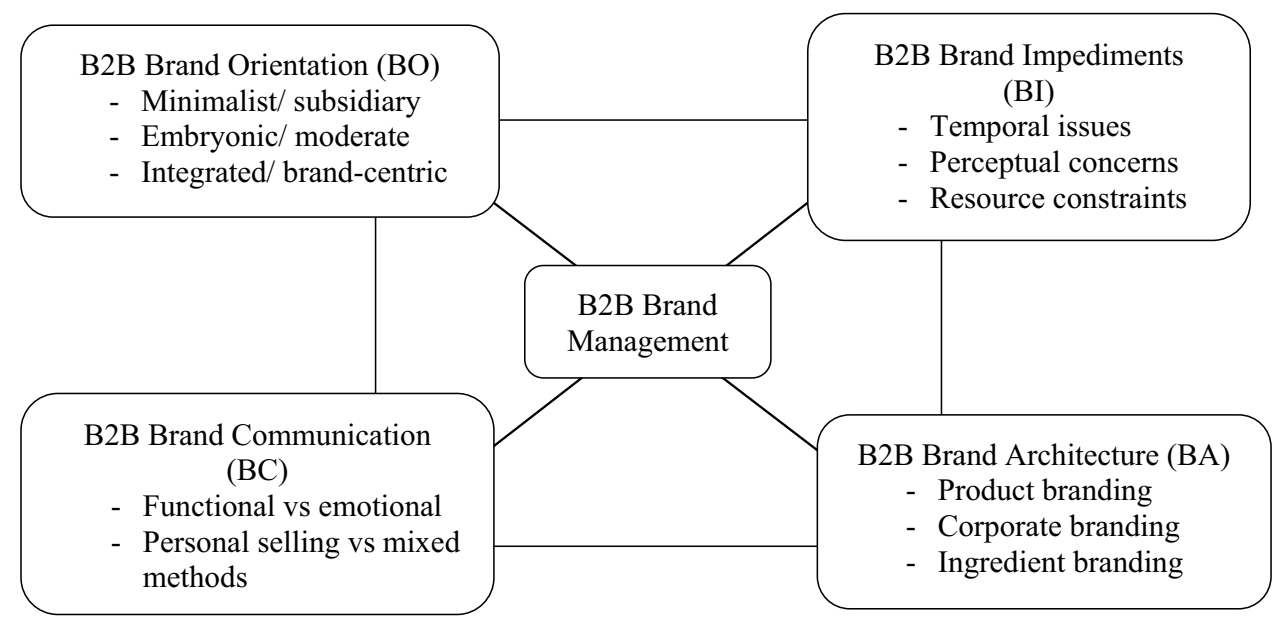




\section{B2B branding impediments}

B2B branding impediments reveal in three aspects: temporal issues, perceptual concerns and resource constraints. The temporal issues relating to the nature of $\mathrm{B} 2 \mathrm{~B}$ practice involve a complex body of products, such that it is difficult to carry out branding properly and promptly (Keller and Kotler 2012). The B2B purchase decision centre embodies a large number of individuals who collectively construct a complex buying behaviour for branding to target that prolongs the branding decisions (Bendixen et al. 2004).

The perceptual concerns of B2B branding refer to how firms perceive branding in the industrial environment. In general, B2B firms see branding as less relevant to their business (Wong and Merrilees 2008). They consider that 'the word brand connotes a gimmicky tactic for a less serious consumer product' (Mudambi et al. 1997, p.434). Moreover, the prevailing emotional approach in $\mathrm{B} 2 \mathrm{C}$ branding has little impact in the B2B context, due to the fact that B2B buyers are profit-driven and budget-constrained; thus, they have to respond more rationally in decision making (Leek and Christodoulides 2012).

B2B exporting literature indicates that country of origin (COO) image has a major influence on product branding. In most cases, a positive $\mathrm{COO}$ image functions as a competitive advantage to promote a brand successfully (Eng et al. 2016). For instance, a fashionable and hedonic image of France helps French firms to gain competitive advantage in exporting cosmetic and textile products (Spence and Essoussi 2010). When the country image is incongruent with the product image, $\mathrm{COO}$ image influences purchase intention indirectly to infer product quality (Wang et al. 2012). Chen et al. (2011) found that some Taiwan firms in labourintensive and price-sensitive industries (e.g. fasteners) experienced difficulties in competing with their Chinese counterparts, as China has gained its reputation on its manufacturing efficiency. In the same vein, a product's geographic origins also influence the product evaluation (Thode and Maskulka 1998; Orth et al. 2005). The concept of region-of-origin provides a more consistent image of product quality and helps sellers to differentiate themselves from both international and local rivals (van Ittersum et al. 2003).

Resource constraint is the other major impediment in B2B contexts. Industrial resource refers to financial capital, human capital and training, infrastructure, knowledge and marketing capacities (Mayer et al. 2012). Building strong brand equity requires a long-term investment in financial support and managerial commitment. This may be troublesome for some small industrial firms, as, in most cases, branding activities are often linked to perceived profit sacrifice with little or limited financial reward (Leek and Christodoulides 2011).
The existing studies on B2B branding and branding impediments are amorphous and inconsistent, without a comprehensive framework to support. There is limited research to provide an overview of how brand impediments interact with other aspects of brand management; for instance, whether the different brand impediment affects a firm's adaptation in branding strategy in the industrial environment.

\section{B2B brand architecture}

Brand architecture strategy reflects how a firm utilises and organises brands; it determines the interrelationship between brands and the role of brands present within a firm (Urde 2003). B2B firms adopt three types of brand architecture strategy: product branding, corporate branding and ingredient branding. Product branding strategy is one of the most prevalent branding strategies in consumer markets. In a B2B application, product branding is less popular due to the industrial product variation and short product life cycles (Baumgarth 2010). Corporate branding is more widespread in B2B sectors (Aspara and Tikanen 2008). The concept of corporate brand is often interchangeable with corporate identity, corporate reputation and corporate image (Keranen et al. 2012). In practice, the corporate branding task is assigned at the top managerial level (Kollmann and Suckow 2007), and it functions as a representative of an organisation (Simoes et al. 2015).

In a comparison with product brands, corporate brands possess a strong and explicit connection with an organisation's culture and structure (Merrilees and Miller 2008) and the aim is to cultivate stakeholders' attachment to the organisation (Balmer 2001; Hatch and Schultz 2003), whereas product brands leverage products sales to increase market share. Corporate brands enjoy attention from a wide range of stakeholders, including consumers, employees, supply chain partners, investors, and government organisations (Vallaster and Lindgreen 2011). Compared to product brands, corporate brands are formed in an abstract mode to represent corporate value and to serve diverse stakeholders (Balmer and Greyser 2002).

Ingredient branding, also known as component branding, draws key features of one brand to incorporate in another brand, aiming to pull sales demand from the end market (Desai and Keller 2002). The ingredient brand best suits industrial goods, with 'ingredients' being the crucial component of the final product (Kotler and Pfoertsch 2010). The best illustrations are Intel, Gore-Tex, and NutraSweet that are often integrated into other host brands (Kotler and Pfoertsch 2010; Moon and Sprott 2016). Such brand alliance strategy offers a number of benefits to both host brand and ingredient brand-i.e. it helps both firms involved to reduce costs and risks (Vaidyanathan and Aggarwal 2000), form a 
positive product image (Bengtsson and Servais 2005) and gain a competitive advantage (Radighieri et al. 2014).

The applications of different types of brand architecture are compatible and integrative, and it varies from context to context. Richter (2007, cited in Baumgarth 2010) stated that $31 \%$ of firms applied corporate branding strategy and approximately $47 \%$ enjoyed a mixture of branding strategies that combines the corporate branding with other branding strategies. The current research, however, has yet obtained an in-depth investigation on the application of brand architecture strategies in the relationship with brand orientation in the B2B context, which invites further exploration (Strebinger 2014).

\section{B2B brand communication}

Brand communication in consumer markets focuses on creating brand awareness, forming brand association, building brand loyalty, and creating positive brand equity (Keller 2013). In B2B contexts, the central focus of brand communication is to disseminate benefits and advantages of products or services to customers (Kotler and Pfoertsch 2006), and help customers to create their values that can be integrated in the supply chain (Biemans 2010). To achieve these objectives, B2B vendors apply a number of communication tools to reach their customers, such as personal selling, direct marketing, public relations, trade shows and sales promotion (Kotler and Pfoertsch 2006; Sharma 2016). Product packaging is a traditional communication vehicle to project a product's quality and generate a buyer's first impression of the product and brand (van Rompay et al. 2014); it is congruent with a brand's overall image (Underwood et al. 2001; Ampuero and Vila 2006).

In general, branding communication is delivered through two approaches: a functional approach and an emotional approach. The nature of industrial business is a contractbased exchange process with specifications in practical and pragmatic functionalities among B2B firms (Candi and Kahn 2016). Branding through a functional approach by explicitly displaying the products' qualities, functionalities, prices and distributional channels has a predominant position in B2B brand communication (Lilien et al. 2010). Some scholars, however, have raised their voices in the call for an emotional approach to B2B branding. Ward and Webster (1991) claimed that the B2B buying decision also involves 'emotions' in addition to 'rational' processes as they serve both the organisation's and the individual's needs. Researchers have pointed out the importance of emotional value in the B2B context (Prior 2013; Candi and Kahn 2016) but, overall, the studies on an emotional approach in B2B contexts are scarce.

Following the development of digital marketing communication, B2B firms have become more appreciative of online communication platforms as a tool with which to enhance business relationships and reduce costs (Sharma 2002). Internet-based platforms-i.e. B2B online forums, trading websites and chatrooms-help firms to communicate branding more effectively. Nonetheless, B2B firms remain slow adopters of the social media applications (Jarvinen et al. 2012). Lacka and Chong (2016) claimed that this is due to the nature of interactions between business partners on building trust relationships. B2B firms perceive the irrelevance of and uncertainty around social media usage as their interaction takes place in a more direct and intense form. Other barriers relate to the absence of relevant training in and financial support for the social media applications (Michaelidou et al. 2011).

Overall, B2B brand communication mediums have progressed from a dominance of the personal selling approach in the early research (Hutt and Speh 2001) to an employment of a mixture of communication vehicles to disseminate the branding message to the targeted segments. In a way, this helps to position a brand with clear points of difference (Keller 2013). The current research nevertheless, did not specifically look at how a firm approach different brand communication channels in the B2B environment, and whether the adaptation of various brand communication methods are affected by other aspects of B2B brand management.

\section{Methodology}

\section{Research setting and procedure}

This study adopts an exploratory approach to investigate the complexity of branding issues. To align with other B2B branding studies (i.e. Kuhn et al. 2008; Malaska et al. 2011; Leek and Christodoulides 2012), we employ a qualitative method - the interview - to serve the exploratory nature of investigation (Sekaran and Bougie 2010).

The sample comprises Chinese private manufacturers from different industries for a number of reasons: first, Chinese private enterprises are the largest contributors to the national economy development (Liang et al. 2014). They are the major force of exporting 'Made in China' products worldwide, accounting for over $46 \%$ of the national total export volume in 2016 (Ministry of Commerce of the People's Republic of China 2016).

Second, past research has focused on the international performance of Chinese state-owned firms (Child and Rodrigues 2005), e.g., the Haier Group (Liu and Li 2002). Notably, the responding firms of these studies were supported by the Chinese government and public institutions; however, the majority of privately owned enterprises do not have the privilege of institutional support (Siu 2005; Zhu et al. 2012) and so pursue branding with limited resources and scant 
knowledge. The dearth of academic interest in the branding of private manufacturers leaves room for further investigation. Thus, it is important to understand their branding performance to expand the current knowledge on $\mathrm{B} 2 \mathrm{~B}$ branding in emerging markets.

A recent review on B2B branding states a lack of attention in understanding branding issues from a multi-industry setting (Keranen et al. 2012). Homburg et al. (2010) claimed that avoiding a multi-industry setting fails to consider the nature of industrial markets of accommodating the complex nature of industrial buying markets (Roberts and Merrilees 2007; Gomes et al. 2016). Thus, our sample selection on a multi-industry basis contributes to the methodological variation in B2B branding literature (Keranen et al. 2012).

Snowball sampling was used to collect the data. Initially, through a B2B trading website, we identified a B2B chatroom that comprises a large number of private manufacturers and members in the chatroom were approached for interviews. Potential interviewees were asked to recommend other candidates who they believed could contribute to the field of study (Malaska et al. 2011). We further explored potential business owner-managers through guanxi, the personal contact networks in China, to enrich the data. Business owner-managers were chosen to supplement the quality of data because they possess a wide range of competences in managing and maintaining their business (Man and Lau 2000), and these competencies in turn provide great insights to improve the market performance (Raymond et al. 2012). Before confirming their willingness to participate, all candidates were informed of the research agenda and the purpose of the interview.

The interviews were conducted over the telephone and via Skype as the sample group members are geographically spread. Past research claimed that there is no significant difference in the reliability of the interview results generated by telephone and face-to-face modes (Ward-King et al. 2010). In addition, the telephone mode offers informants a comfortable and convenient setting from which to discuss sensitive topics (Holbrook et al. 2003). Interview questions were semi-structured, and a brief interview guide is presented in Appendix 1. We chose to have a relaxed interview structure to allow respondents to talk freely (Ritchie and Lewis 2003), and sought permission to record each interview.

We have undertaken data analysis alongside data collection. After conducting more than 10 interviews and analysis of the collected data, we noted a repetitive pattern occurring in the coding process and additional data collection became redundant (Kerr et al. 2010). Past studies indicated that a saturation of themes occurred within 12 interviews, and the majority of basic elements of themes are often identified as early on as in six interviews (Guest et al. 2006; Namey et al. 2016; Hennink et al. 2017). We decided to terminate data collection after completing 17 interviews, as strong evidence suggested that we had reached a point where no further issues would emerge from the data, indicating that all relevant themes have been identified, established and categorised (Bryant and Charmaz 2007). Among these 17 private manufacturer cases, 10 interviews were with executives and salespeople who act as brand ambassadors with three to 15 years of manufacture exporting experience. The remaining seven interviewees were business owner-managers. Table 1 provides profiles and characteristics of the respondents. Any information that could disclose the identity of the respondent has been eliminated to ensure confidentiality.

\section{Data analysis}

Data were analysed through both qualitative and quantitative approaches to complement the results. First, we followed an inductive approach by employing thematic analysis to process the data. Following the guidelines for the thematic analysis process (Attride-Stirling 2001; Braun and Clarke 2006), we explored qualitative data in detail. Starting with data cleaning and detailed reading, we identified codes from text, analysed and examined text and codes and then induced codes into various themes and patterns that reflect the nature of the data. The qualitative approach discovered a number of themes and patterns. We further grouped and categorised the themes, and excluded some themes that are irrelevant to the study and yet to meet the objective of this research. After a series of analysis, coding, recoding, grouping and regrouping, we formed a list of categories that are in line with brand management literature, including brand orientation, branding impediments, branding architecture, and branding communication.

Through the standard coding process, we construct Table 2 to show the properties of the contributions from manufacturer cases in corresponding to each category.

To ensure the credibility, transferability, dependability and conformability of the qualitative data analysis, both authors were involved in translation, back translation, coding, categorising and summarising of patterns to crosscheck the conceptual development. The data reliability was achieved through Miles and Huberman (1994) approach, and the 17 cases were coded independently according to the descriptions listed for each dimension to obtain data reliability. Each theme and description of the four categories were discussed, reviewed and finalised by authors and the result of overall inter-coder reliability reached at the satisfactory level (Kassarjian 1977). The differences between coders among all sub-dimensions for relevant cases were then discussed among authors until final consensus was reached. The mutually agreed results were used for further analysis. Moreover, the tentative concepts and schema identified by the authors were sent to the interviewees for comments, and were then further revised and reformed based on their feedback. To 
Table 1 Manufacturers' profile

\begin{tabular}{|c|c|c|c|c|c|c|c|}
\hline Manufacturer & Interviewee position & Interview mode & Industries/products & $\begin{array}{l}\text { Firm export- } \\
\text { ing age } \\
\text { (years) }\end{array}$ & $\begin{array}{l}\text { Firm size (no. } \\
\text { of employees) }\end{array}$ & $\begin{array}{l}\text { Direct export (DE)/ } \\
\text { indirect export (IE) }\end{array}$ & $\begin{array}{l}\text { Duration } \\
\text { (in min) }\end{array}$ \\
\hline M01 & ESM & Telephone & Bathroom lighting & $4-5$ & $<50$ & DE \& IE & 40 \\
\hline M02 & Founder & Telephone & Natural stone & $8-9$ & $<50$ & IE & 30 \\
\hline M03 & Founder & Skype-video & Toothbrush & $5-6$ & $<100$ & DE \& IE & 40 \\
\hline M04 & CEO Assistant & Telephone & fasteners & $9-10$ & $<300$ & DE \& IE & 34 \\
\hline M05 & ESM & Telephone & $\begin{array}{l}\text { Disposal medical sup- } \\
\text { plies }\end{array}$ & $3-4$ & $<150$ & DE \& IE & 40 \\
\hline M06 & ESM & Telephone & Computer & 10 & $<500$ & DE \& IE & 25 \\
\hline M07 & Founder & Telephone & Packaging processing & 5 & $<50$ & IE & 20 \\
\hline M08 & ESM & Skype-voice & Speaker & $7-8$ & $<200$ & DE \& IE & 55 \\
\hline M09 & ESM & Telephone & LED screen & $8-9$ & $<100$ & DE \& IE & 30 \\
\hline M10 & ESM & Telephone & Sound proofing material & 10 & $<50$ & IE & 70 \\
\hline M11 & ESM & Telephone & Charger & $3-4$ & $<100$ & DE \& IE & 30 \\
\hline M12 & ESM & Telephone & LED lighting & 7 & $<50$ & DE \& IE & 50 \\
\hline M13 & Founder & Telephone & Accessories & $9-10$ & $<150$ & DE \& IE & 25 \\
\hline M14 & ESM & Skype-voice & Electronic product & 8 & $<150$ & DE \& IE & 50 \\
\hline M15 & Founder & Telephone & $\begin{array}{l}\text { Promotional textile, i.e. } \\
\text { flag }\end{array}$ & 11 & $<150$ & DE \& IE & 20 \\
\hline M16 & ESM & Skype-voice & Stainless steel tube & 5 & $<100$ & DE \& IE & 50 \\
\hline M17 & ESM/BP & Telephone & Toothbrush & 10 & $<250$ & DE \& IE & 52 \\
\hline Total & & & & & & & 661 \\
\hline
\end{tabular}

$E S M$ executive sales manager, $B P$ business partner

Table 2 Conceptual properties of cases

\begin{tabular}{|c|c|c|c|c|}
\hline $\begin{array}{l}\text { Manufacturer } \\
\text { case }\end{array}$ & $\begin{array}{l}\text { Brand orientation } \\
\text { Minimalist/moder- } \\
\text { ate/coordinated }\end{array}$ & $\begin{array}{l}\text { Branding impediments } \\
\text { Insufficient resource/inadequate knowl- } \\
\text { edge/country of origin (COO) image }\end{array}$ & $\begin{array}{l}\text { Branding architecture } \\
\text { Corporate branding active/non- } \\
\text { active mixed branding }\end{array}$ & $\begin{array}{l}\text { Branding communica- } \\
\text { tion } \\
\text { Conventional/pro- } \\
\text { gressive/determined } \\
\text { approach }\end{array}$ \\
\hline M01 & Moderate & Insufficient resource & Corporate branding-non-active & Progressive \\
\hline M02 & Minimalist & Insufficient resource & Corporate branding-non-active & Conventional \\
\hline M03 & Coordinated & Inadequate knowledge & Mixed & Progressive \\
\hline M04 & Moderate & Inadequate knowledge & Corporate branding - active & Progressive \\
\hline M05 & Moderate & COO image & Corporate branding-active & Progressive \\
\hline M06 & Coordinated & COO image & Mixed & Determined \\
\hline M07 & Minimalist & Inadequate knowledge & Corporate branding-non-active & Conventional \\
\hline M08 & Moderate & COO image & Corporate branding_-active & Progressive \\
\hline M09 & Minimalist & Inadequate knowledge & Corporate branding - non-active & Progressive \\
\hline M10 & Minimalist & Insufficient resource & Corporate branding-non-active & Conventional \\
\hline M11 & Moderate & COO image & Mixed & Progressive \\
\hline M12 & Moderate & Insufficient resource & Corporate branding -active & Progressive \\
\hline M13 & Moderate & COO image & Corporate branding-active & Progressive \\
\hline M14 & Moderate & Inadequate knowledge & Mixed & Determined \\
\hline M15 & Minimalist & Inadequate knowledge & Corporate branding-non-active & Progressive \\
\hline M16 & Moderate & COO image & Corporate branding-active & Progressive \\
\hline M17 & Moderate & Inadequate knowledge & Mixed & Progressive \\
\hline
\end{tabular}


support the analysis, we provide evidence in the form of excerpts from the interview data in Appendix 2.

To complement the qualitative findings, we applied Categorical Principal Component Analysis (CATPCA) in SPSS for further analysis. CATPCA is an appropriate method for categorical records in qualitative data and small samples (Odekerken-Schröder et al. 2010). Based on the alternating least squares (ALS) algorithm, CATPCA utilises an optimal least squares scaling process where original data are transformed so that their overall variance is maximised (Gifi 1990). CATPCA does not assume multivariate normality and linear relationships between variables. The statistical analysis approach is formulated by means of a loss function by the ALS and consequently leads to optimally scaled scores on each factor; thus, it provides a flexible framework for parametrisation (Michailidis and de Leeuw 1998).

One of the main advantages of CATPCA is that it has standard provisions for the graphical representation, for example, in the form of biplots on the representation of case respondents on each specific dimension. This is very useful as it provides a tool to objectively capture nuances of every case respondent on the specific dimension which could not be identified by using multiple case research (Eisenhardt and Graebner 2007). Given that the data set is heterogeneous and diverse as case respondents are from different industries, using CATPCA may be especially advantageous over multiple case research when a data set contains variables that measure different types of characteristics and do not all have the same range. Nevertheless, CATPCA is an explorative technique and there is a risk of fitting structures that are very sample specific (Meulman et al. 2004). The application of CATPCA analysis method is common in social and behavioural sciences research due to the non-numeric nature of the data (Meulman et al. 2004; Linting et al. 2007), and it has been expanded in the marketing research, branding and Chinese private small-firm marketing (Siu 2008; OdekerkenSchröder et al. 2010). We consider that the use of CATPCA is appropriate for the present categorical variables set in describing how the four $\mathrm{B} 2 \mathrm{~B}$ branding aspects influence the branding decisions of Chinese private firms.

\section{Findings}

\section{B2B brand orientation}

On reviewing the transcripts, we observed three categories of brand orientation, which is in line with previous research (see Wong and Merrilees 2005; Khan and Ede 2009; Mitchell et al. 2015). These are (1) a minimalist orientation with a low level of brand orientation and little or no desire to brand; (2) a moderate orientation when firms have developed a good awareness of branding; and (3) a coordinated brand orientation whereby firms incorporate branding into their business activities.

\section{A minimalist brand orientation}

Around 30\% of interviewed firms belong to the group with a minimalist brand orientation. These firms perceive that branding is irrelevant to business growth and that they should minimise resources for branding. We found a popular belief among firms that a brand has a limited application to the industrial market, as one business owner illustrated: '[...] almost no one cares about branding in this industry, simply because we don't need it' (M2).

Findings show that the different levels of brand orientation may relate to the different products and business models. Manufacturers engaged in processing and assembly businesses, or their operations under the original equipment manufacturer (OEM) model, have expressed little or no interest in branding. This is particularly the case for M10 in producing ingredient materials (soundproofing materials) and M15 in manufacturing promotional goods (i.e. flags, pens) as typified by M10 in the quote below:

This soundproofing material does not require branding. Our business model is that customers visit us, offer us an order, and specify a deadline, then we produce it within the time frame. No branding is required. (M10)

\section{A moderate brand orientation}

More than half of the interviewed firms belong to the moderate brand orientation category. Firms in this group have expressed their interests in branding and have developed a good branding awareness. They acknowledge the power of the brand in building customer trust and generating financial return:

A brand is not a logo, but it represents the value of a company. Premium brands can charge you thousands of dollars for a bag, just like Louis Vuitton does. This is difficult to achieve for a bag from us with no brand. (M4)

Within this group, we noticed that even though they have addressed the significance of branding to their business, they showed little commitment to branding activities; for instance, M5 expressed, 'We won't spend too much time on brand promotion', while M13 stated, 'We have our own brand, but we do not promote it...'. This shows a discrepancy between the reality and the ideal. Ideally, building a successful brand will enhance corporate performance as a brand acts as a compass to guide a firm's strategic direction 
(de Chernatony 1999). In reality, however, many B2B firms fall short in allocating resources to support branding. This is partly because firms' reliance on OEM business transactions leaves little room, financially, for them to pursue branding.

\section{A coordinated brand orientation}

Two firms (M3 and M6) showed signs of attempting to develop brand vision and coordinating branding activities on business performance. This group has revealed a progressive awareness of branding in business activities. They regard themselves as an example of brand acceptance in business practice. We categorised this group as a coordinated brand orientation. The recognition and application of brand value to the business practice is what distinguishes them from the moderate brand-oriented firms.

I always tell my employees that we put so much resources on branding-maybe a few million Yuan. The brand is just like your baby; we should not let it die in the crib. We should try our best to build the brand, build a famous brand, and we are working on it.... (M3)

M6 has implemented branding practice in the home market. Early research indicated that starting from a domestic market helps companies to gain experience in a familiar market before entering an international market (Cavusgil 1984).

We have been practicing branding in the domestic market. The Chinese market is big enough. We will continue exploring the international market. We used to be export-oriented; now we will redirect part of our attention to the domestic market for branding. (M6)

The findings in brand orientation show some interesting insights. A minimalist brand orientation tends to be small firms (i.e. M02, M07, M10) with less than 50 employees, and/or their business nature are in the assembly line with homogeneous products (M09, M15). A moderated and a coordinated brand orientation, nevertheless, are determined by the level of branding awareness and firms' commitment in branding rather than a firm's size and the industry nature.

\section{B2B branding impediments}

To investigate the possible impediments that thwarted firms in their quest to become brand-oriented, we asked respondents to describe the barriers that they have encountered in developing brands in the manufacturing environment. Our data outline a number of branding impediments that reflect the literature, such as country-of-origin effect (Chen et al.
2011), inadequate knowledge (Mudambi et al. 1997) and insufficient resources (Webster and Keller 2004).

\section{Country-of-origin effect}

We have learned that the negative image of 'Made in China' is one of the major factors that discourage Chinese manufacturers from pursuing branding. Since the launch of the Open Door policy in the late 1970s, China welcomed multinational corporations with its cheap and abundant labour resources. Having exported vast quantities of 'Made in China' products to overseas markets, China has earned herself the title of 'World Factory'. Meanwhile, an image of low-quality and cheap Chinese goods has gradually implanted in the buyer's mind (HaBrookshire and Yoon 2012), deterring Chinese manufacturers from purchasing own brands. Our respondent firms (M5, M6, M8, M11, M13, and M16) have addressed this issue:

...even if we want to do branding, the customers do not care about our brand; they want a Chinese product at a cheap price.... (M16)

Overseas customers came to us for our product, not the brand. They have their own name and logo, even the small buyers request that they have their own names on the product. They do not want our brand. (M8)

M6 has complained that despite all efforts in promoting the factory brand at international events, they received more requests for OEM production than for their own branded products. Buyers' perceptions of 'Made in China' products as low cost, low quality, and mass production leaves little room for Chinese manufacturers to develop their own brands.

\section{Inadequate knowledge}

We found that some firms hold inadequate knowledge on the value of brand in $\mathrm{B} 2 \mathrm{~B}$ markets, particularly the firms operating in component and assembly production lines. They claim it is a waste of time and budget to invest in branding for the low-value products or services. Rather, they view branding as a business strategy that belongs to the consumer market and the large firms that produce high-technology and value-added goods.

The main reason (for not branding) is the product itself - fasteners - which, unlike those home appliances, do not need branding. (M4)

We provide printing services; we do the printing for them. This kind of low-technology product or service does not need branding. (M7) 
The B2B buying process involves a greater number of actors over a longer timespan compared to the case in the consumer market (Webster and Keller 2004), which creates difficulties in implementing branding strategies (Kotler and Pfoertsch 2006). This is even more challenging for firms in the manufacturing and exporting sectors, as M3 claimed that it is hard to satisfy international buyers with various needs and demands. The pluriformity of the market impedes firms from sketching out a clear brand vision, thereby making it difficult for them to position a brand.

\section{Insufficient resources}

Resource-constraint impediments are more salient and common in B2B markets, particularly for these small-sized firms (Mitchell et al. 2015). We have outlined a list of branding impediments that relate to the resource insufficiency; these include insufficient financial support, lack of marketing capacity, and poor management knowledge. These findings echo the previous research on B2B branding barriers (Leek and Christodoulides 2011). M1 and M2 reflected that insufficient resources relate to being small firms and lacking economies of scales (both firms have fewer than 50 employees):

It's related to the size of the manufacturer. We are not big in business, we are a small firm... We don't have sufficient support for branding; we have insufficient office staff, manufacturing equipment, etc., to support branding. (M1)

Insufficient resources can occur not only in the form of business size and financial backup, but also from a lack of managerial vision and motivation in branding. Both firms (M10 and M12) indicate that management support for a firm's strategic direction in branding is important, as one sales executive noted: 'the boss does not care for branding, he does not want to spend money on branding, so we don't do branding' (M10).

The brand impediments vary in the different type of business. In general, small size firms suffer more from the insufficient resources; firms directly deal with the international market encounter more barriers in the negative $\mathrm{COO}$ image. The inadequate knowledge is shared with most firms regardless the size of business and the nature of industry. A limited knowledge in branding leads firms to believe that branding is less relevant for SMEs in the B2B market (Wong and Merrilees 2008; Leek and Christodoulides 2012).

\section{B2B brand architecture}

We found that manufacturers have adopted two types of branding architecture strategies-the corporate branding strategy and a mixed branding strategy that combines corporate branding and product branding. We have not found evidence to support a firm that only focuses on developing product branding. In general, the product branding strategy is more popular in the B2C market with limited implications in the industrial market (Baumgarth 2010).

\section{Corporate branding}

We found that corporate branding is the most prevalent branding architecture adopted by interviewed firms (over $70 \%$ of firms). This supports previous reports that corporate branding is the most applicable branding strategy in B2B sectors (i.e. Aspara and Tikanen 2008). Data show two levels of practice in the corporate branding-non-active practice and active practice.

The group with non-active corporate branding practice does not consider corporate branding as a form of branding strategy, and they discard the corporate name from the branding. We found six firms (M1, M2, M7, M9, M10 and M15) that belong to this group. These firms have little interest in branding the corporate name. They often assert, 'We don't have a brand...', or 'we have a corporate name, but no brand.' In their view, brand and branding are the practices for well-known companies in consumer markets.

Six firms (M4, M5, M8, M12, M13 and M16) fall into the group with active corporate branding practice. This group perceives that a corporate brand functions as a convenient name for legal identity and differentiation purposes. Their main business focuses on OEM and contract manufacturing, but they have actively engaged in promoting the manufacturer's name to gain more sales. This is illustrated in the following quotes:

Our corporate name is the brand and we use it on the products we sell if the customers are willing to buy our branded products.... (M12)

We have our own brand (corporate name)...we use the company logo in Hong Kong electronic tradeshows .... (M8)

\section{Mixed branding}

We found that five firms have adopted distinctive brand architecture by mixing corporate branding and product branding (M03, M06, M11, M14, and M17). This group started applying the corporate name in the exporting market to attract OEM deals. By so doing, they have redirected their attentions to the domestic market by introducing a new product name.

International deals are mostly for OEM. We do apply product branding in the domestic market. You can find 
our products listed in QQ space, an online platform .... (M3)

Most of our production line is for OEM. We do our own branding in the domestic market, maybe also expand a little in overseas markets, but OEM is still dominating. (M6)

We have further explored their motivations in obtaining a product branding strategy in addition to corporate branding. Findings reveal that firms allocate a brand to the product only for identification purposes; as M6 and M14 state:

We use the same brand for international and domestic markets, the former is in English, and the latter is in Chinese. (M6)

Because the domestic market needs a name, we put a Chinese name on it. (M4)

This indicates that where product branding is applied, it is mainly to provide product identity and stimulate product sales, not to purposefully develop branding skills.

Notably, interview data reveal no evidence of ingredient brand application. Respondents in the component production business regard branding as 'a waste of time and unnecessary' (M4). Previous studies have specified a list of criteria for ingredient branding application; for instance, the ingredient product must be essential to the final goods, and it must be innovative and creative (Norris 1992; Kotler and Pfoertsch 2006). Corresponding to the criteria introduced by Kotler and Pfoertsch (2006), we found that ingredient products in our data are mainly the substitutes for the final products rather than the essential components. They are not innovative or creative and, thus, constrained firms from developing ingredient branding.

In the relation to a firm's size, we found that the majority of firms that adopted the non-active corporate branding strategy are small in size, with assembly and mass production in business nature. Larger firms are more active in corporate branding practice, or they have adopted product branding strategy in addition to the corporate branding to explore domestic markets. We have not found a strong evidence to connect the product variations with the adoption of different branding strategy.

\section{Brand communication}

We found that firms adopted a number of communication modes to deliver branding messages, such as through personal communication, packaging, e-commerce platforms, and tradeshows. Overseeing the data, we observed three types of approach to illustrate firms' attitudes when engaging in brand communication-a conventional approach, a progressive approach and a determined approach.

\section{A conventional approach}

Manufacturers with a conventional approach (M2, M7 and M10) use less risky communication channels due to the limited financial support available to them; for example, promoting through B2B e-commerce platforms and packaging. There are various B2B trading platforms available for Chinese manufacturers, such as alibaba.com, and madeinchina. com. These B2B websites help firms to reach a wider audience with little investment; hence, they are particularly appealing among small-size firms.

Most firms have developed a business profile page and uploaded their latest products and services to B2B online platforms. Other conventional communication channels are also popular; include promoting through product packaging and offering discount prices for own brands. These are attractive for small-quantity buyers.

We put the manufacturer's logo on the package... if buyers have no specific requests, we will normally put our company's name, telephone number, and address on the packaging to promote our brand. (M10)

\section{A progressive approach}

Seventy per cent of responding firms follow a progressive communication approach because the key motivation is to increase sales. They actively engage in markets to seek for opportunities to interact with buyers face-to-face, such as visiting buyers' markets and attending international tradeshows. Tradeshows and business exhibitions are recognised as the most effective and powerful ways to build relationships with organisation buyers (Steimer 2016).

We do visit some tradeshows, e.g., Hong Kong electronic shows, but I don't feel that promoting the brand is the key purpose. I think the more important thing is your product and design, as well as the management teams' capacities that can help to gain sales. (M8)

\section{A determined approach}

Two firms (M6 and M14) adopt a determined communication approach. They are highly committed to improve their company's reputation and are motivated to promote brands in the market. Their ambitions are not only to increase the sales growth but also to promote the company internationally. In most cases, firms with a determined branding communication approach have sufficient resources to support their international activities.

Actually we always promote our brand... we attend the Hong Kong tradeshow yearly, people from all over the world come to that show. We also visit the Canton 
Trade Fair, twice a year. The Las Vegas tradeshow in America, we visit on a yearly basis. This year, we have visited the Taipei Trade Fair... We have visited the German fair, the Dubai fair, the South African fair... Through visiting trade fairs, we aim to promote our company internationally. (M6)

The finding in brand communication approach shows that small firms are more likely to adopt a conventional brand communication approach, as they have limited resources and less willing to risk in costly communication channels. Firms undertake a progressive communication approach are mixed with different size, and they are willing to look for opportunities to improve their business sales. Interestingly, we found that two firms undertake the determined approach are relatively larger in size and both are in electronic-related industries. Thus, our finding suggests that a firm's size and the nature of business may influence their attitudes in approaching different branding communication channels.

\section{Identifying B2B branders with CATPCA}

Based on the themes outlined in Table 2, we transformed the identified constructs into categorical variables and assigned numerical value to the categories to quantify the data. Measurements are treated in two types of variables-nominal variables (brand impediment and brand architecture), and ordinal variables (brand orientation and brand communication). Table 3 shows that the two dimensions have eigenvalues of 2.567 and 1.021, respectively, which are greater than 1 (Muelman and Heiser 2012); and the total Cronbach's alpha is .962, which is higher than the minimum .7 value (Lance et al. 2006). The two selected dimensions explain over $89 \%$ of the variance in quantified variables and the results indicate a good fit (Linting and van der Kooij 2012).

We further calculated the branding decision with component loadings in the analysis. Table 4 shows that the first dimension consists of brand orientation, brand architecture and brand communications with loadings of $.924, .925$ and .878 , respectively. We named this dimension 'Strategic

Table 3 Measures of validity of CATPCA. Source: Output of CATPCA conducted using IBM SPSS 24.0

\begin{tabular}{llll}
\hline Model summary & \multicolumn{3}{l}{} \\
\hline Dimension & \multicolumn{2}{l}{ Variance accounted for } \\
\cline { 2 - 4 } & Cronbach's alpha & $\begin{array}{l}\text { Total (eigen- } \\
\text { value) }\end{array}$ & $\begin{array}{l}\text { Percentage } \\
\text { of variance }\end{array}$ \\
\hline 1 & .814 & 2.567 & 64.169 \\
2 & .028 & 1.021 & 25.516 \\
Total & $.962^{\mathrm{a}}$ & 3.587 & 89.685 \\
\hline
\end{tabular}

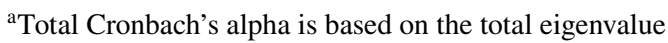

Table 4 Component loadings of factors within branding aspects definitions. Source: Output of CATPCA conducted using IBM SPSS 24.0

\begin{tabular}{llr}
\hline & \multicolumn{1}{l}{ Dimension } \\
\cline { 2 - 3 } & 1 & \multicolumn{1}{c}{2} \\
\hline Brand orientation & .924 & -.313 \\
Brand impediments & .293 & .947 \\
Brand architecture & .925 & -.104 \\
Brand communications & .878 & .125 \\
\hline
\end{tabular}

Variable principal normalisation

Branding Adaptation'. Brand impediments, with a loading of .947, stand alone as the second dimension, and we labelled it 'Branding Hindrance'. Table 5 lists details of the component loadings for each case. We further plot all manufacturer cases into a two-dimensional diagram to construct a visual interpretation. Results show that all cases fell into four clusters with a minimum of three cases for each cluster (see Fig. 2).

Cluster 1 comprises four cases and it is largely characterised by the moderate to coordinated brand orientation (BO), active corporate branding and mixed branding (BA), inadequate brand knowledge (BI) and the progressive to determined approach in communication (BC). Cases in this group are motivated to adopt branding; they actively develop branding capabilities to build corporate images for

Table 5 Component loadings of cases. Source: Output of CATPCA conducted using IBM SPSS 24.0

\begin{tabular}{lrr}
\hline Object scores & & \\
\hline Case number & Dimension & \multicolumn{1}{c}{2} \\
\cline { 2 - 3 } & 1 & -1.393 \\
\hline 1 & -.331 & -1.031 \\
2 & -1.920 & .652 \\
3 & .869 & .770 \\
4 & .658 & -.417 \\
5 & .513 & -.428 \\
6 & 1.026 & 1.331 \\
7 & -1.631 & -.417 \\
8 & .513 & 1.623 \\
9 & -.812 & -1.031 \\
10 & -1.920 & -.447 \\
11 & .620 & -1.592 \\
12 & .369 & -.417 \\
13 & .513 & .848 \\
14 & 1.068 & 1.623 \\
15 & -.812 & -.417 \\
16 & .513 & .740 \\
17 & .765 & \\
\hline
\end{tabular}

Variable principal normalisation 


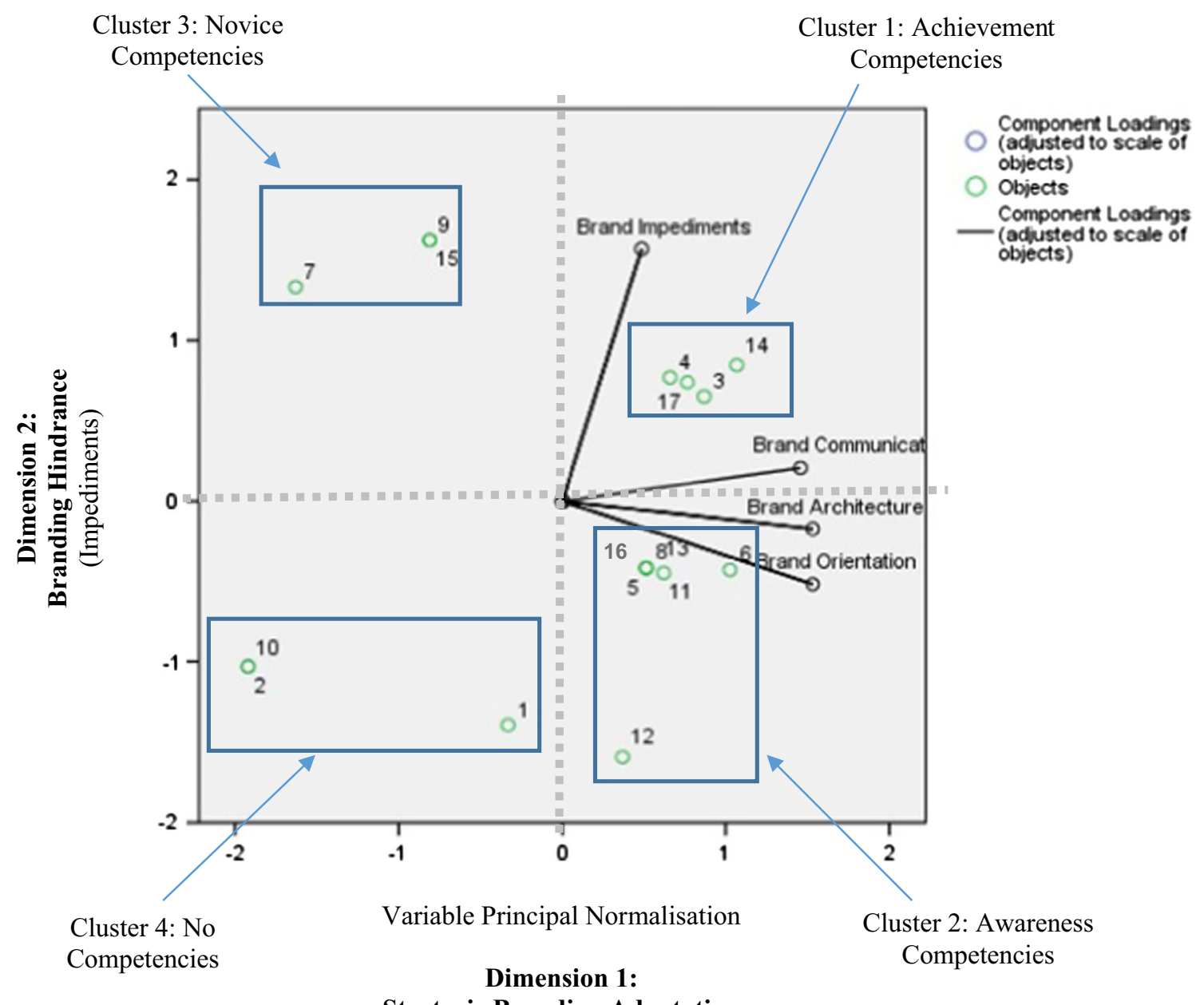

Strategic Branding Adaptation

(Orientation + Architecture + Communication)

Fig. 2 Two-dimensional diagram of cases

business growth. However, due to their strong beliefs in the OEM business model and the nature of the industry that is focused on product, they believe that it is less relevant to their business to adopt active branding. We name this cluster the 'Achievement competencies'.

Cluster 2 gathers the largest number of cases (seven) and it is predominantly characterised by the moderate brand orientation (BO) and active corporate branding to mixed branding (BA); it is mainly affected by a negative COO image (BI), and it adopts the conventional approach in brand communication (BC). Cases in this group are well aware of the strategic importance of branding. They have developed legal identities for brands and achieved some branding capabilities. Nevertheless, this group has the strong belief that their production base represents their distinctive competencies in branding and they stick to existing channels for promotion. Thus, we name this cluster the 'Awareness Competencies'.
Both clusters 3 and 4 contain equal numbers of cases (three). Cluster 3 is primarily defined by the minimalist brand orientation (BO), non-active to active corporate branding (BA), inadequate brand knowledge (BI), and conventional to progressive approach in brand communication (BC). This group operates under the OEM business model and perceives that branding is not relevant or necessary to their businesses. They have inadequate brand knowledge and prefer to uphold existing channels for branding and business promotion. Thus, we named it the 'Novice competencies'.

The last cluster shows a mix of respondents with the minimalist to moderate brand orientation (BO), non-active corporate branding (BA), insufficient branding resources (BI), and conventional to progressive approach in brand communication (BC). Respondents in this group have developed a 'not-for-me' mentality. In the case of M01, they may have acquired branding knowledge and have passively formed a good branding awareness through their contracted branding 
company. Nevertheless, this group allocates very limited resources for branding and contributes minimal activities to the support of brand development. They retain the existing branding channels for brand promotion; thus, we term this cluster 'No competencies'.

\section{Discussion and implications}

Based on the analysis, we have developed an insightful branding schema germane to both branding adaptation and brand hindrance (see Table 6). Our small-scale exploratory study has empirically examined the heterogeneity in manufacturer's branding by identifying four illustrative industrial branders.

Strategic branding adaptation encompasses brand orientation, communication and architecture application. Some of our findings are in line with the existing literature; for instance, the three types of brand orientation in the minimalist, moderate and coordinated brand orientations aligns with Wong and Merrilees (2005). We further confirmed that the corporate branding strategy is the most popular branding strategy applied in B2B SMEs, supporting the earlier research by Aspara and Tikanen (2008), and Kotler and Pfoertsch (2006). We found that the level of brand orientation determines a firm's branding practice. 'No-competencies' and 'novice competencies' branders show a low level of branding orientation, resulting in a less active and more conventional communication approach. The majority of firms in these two categories are smaller size and practice in assembly and mass production business. An increasing level of brand orientation in the 'awareness competencies' brander shows a progression in brand communication. The 'achievement competencies' branders have a high level of brand orientation; they are larger size and more active in and committed to branding. The progression in brand competence partially relates to a firm's business nature and size. Brand competence firms mainly are those who have developed a sizeable business scale, and their business nature requires them to develop a distinctive brand to compete in the market.

Brand hindrance are constructed by branding impediments, which, based on the literature, comprise three types of barrier-insufficient resources, inadequate knowledge, and a negative $\mathrm{COO}$ image. Insufficient resources mainly affect the no-competencies branders in smaller sized firms, aligning with the previous literature (see Wong and Merrilees 2005; Ojasalo et al. 2008), indicating the smaller firms focus more on sustaining their daily operations than on paying attention to branding. A small-size firm has its 'survival mentality' (Hirvonen and Laukkanen 2014) that perceives

Table 6 A tentative schema for BSB strategic branding management

\begin{tabular}{|c|c|c|c|}
\hline \multirow[t]{2}{*}{ Types of B2B branders } & \multirow[t]{2}{*}{ Case Number } & \multicolumn{2}{|l|}{ B2B branding competencies } \\
\hline & & $\begin{array}{l}\text { Dimension } 1 \\
\text { Branding adaptation }\end{array}$ & $\begin{array}{l}\text { Dimension } 2 \\
\text { Brand hindrance }\end{array}$ \\
\hline $\begin{array}{l}\text { Achievement competencies } \\
\text { Have a strategic branding concept } \\
\text { Develop branding capabilities for growth } \\
\text { No need to adopt active branding } \\
\text { Actively building brand images }\end{array}$ & $\begin{array}{l}\text { M03 } \\
\text { M04 } \\
\text { M14 } \\
\text { M17 }\end{array}$ & $\begin{array}{l}\text { High orientation and high adaptation } \\
\text { (BO) Moderate to Coordinated brand orienta- } \\
\text { tion } \\
\text { (BA) Active and mixed corporate branding } \\
\text { (BC) Progressive to determined approach in } \\
\text { communication }\end{array}$ & $\begin{array}{l}\text { Inadequate knowledge } \\
\text { (BI) Inadequate knowledge }\end{array}$ \\
\hline $\begin{array}{l}\text { Awareness competencies } \\
\text { Know about the strategic importance of brand- } \\
\text { ing } \\
\text { Have legal identity and develop branding } \\
\text { capabilities } \\
\text { Our production is our brand } \\
\text { Stick to existing channels for promotion }\end{array}$ & $\begin{array}{l}\text { M05 } \\
\text { M06 } \\
\text { M08 } \\
\text { M11 } \\
\text { M12 } \\
\text { M13 } \\
\text { M16 }\end{array}$ & $\begin{array}{l}\text { High orientation and high adaptation } \\
\text { (BO) majority with moderate brand orientation } \\
\text { (BA) Active corporate branding } \\
\text { (BC) majority with progressive approach in } \\
\text { communication }\end{array}$ & $\begin{array}{l}\text { COO image } \\
\text { (BI) mainly with COO image }\end{array}$ \\
\hline $\begin{array}{l}\text { Novice competencies } \\
\text { Adopt the OEM business model and branding is } \\
\text { not relevant to business } \\
\text { No need to adopt branding } \\
\text { Inadequate brand knowledge } \\
\text { Stick to existing channels for promotion }\end{array}$ & $\begin{array}{l}\text { M07 } \\
\text { M09 } \\
\text { M15 }\end{array}$ & $\begin{array}{l}\text { Low orientation and low adaptation } \\
\text { (BO) Minimalist brand orientation } \\
\text { (BA) Non-active to active corporate branding } \\
\text { (BC) Conventional to progressive approach in } \\
\text { communication }\end{array}$ & $\begin{array}{l}\text { Inadequate knowledge } \\
\text { (BI) Inadequate knowledge }\end{array}$ \\
\hline $\begin{array}{l}\text { No competencies } \\
\text { 'Not for me' mentality } \\
\text { No branding activity } \\
\text { Limited resources for branding } \\
\text { Stick to existing channels for promotion }\end{array}$ & $\begin{array}{l}\text { M01 } \\
\text { M02 } \\
\text { M10 }\end{array}$ & $\begin{array}{l}\text { Low-level orientation and low adaptation } \\
\text { (BO) Minimalist to moderate brand orientation } \\
\text { (BA) Non-active corporate branding } \\
\text { (BC) Conventional to progressive approach in } \\
\text { communication }\end{array}$ & $\begin{array}{l}\text { Insufficient resources } \\
\text { (BI) Insufficient resources }\end{array}$ \\
\hline
\end{tabular}


branding as the last thing on their 'to-do list' as they suffer more from resources deficiency (Krake 2005).

The impediment in inadequate branding knowledge is more salient among the novice competencies branders and the achievement competencies branders. These firms uphold a belief that branding is less applicable for industrial goods and is, therefore, less appreciated in B2B markets, which aligns with the existing literature (Leek and Christodoulides 2012). In terms of country-of-origin effect, $35 \%$ of cases report that a negative country image impedes their decisions in brand building while they directly deal with international buyers. This is particularly the case with the awareness competencies branders where the negative quality image of 'Made in China' products held among buyers has eroded their ambitions about and confidence in branding. Our findings in $\mathrm{COO}$ effect has provide further evidence in support the previous literature in international buyers infer and evaluate product with an overall image of the country of origin (Wang et al. 2012; Eng et al. 2016).

We outlined illustrative quotes to support the branding schema (see Appendix 3). SMEs as no-competencies branders, branders with novice competencies and branders with awareness competencies could manipulate the four branding concepts in the schema to become branders with achievement competencies, thereby enhancing their corporate performances.

\section{Contributions and implications}

Acknowledging the small-scale explorative feature of this study, our intention is not to make a generalisation but to pave the way for future investigation. Thus, we offer some unique contributions.

Theoretically, through the existing B2B branding literature, we constructed four distinctive branding dimensions to reveal their relationship and interconnection in building a strong B2B brand. Our study extended the existing branding orientation typology, which has been generated from SMEs in the consumer market (Mitchell et al. 2015), into the manufacturing industry. We found that the level of brand orientation relates to the firm's size and other branding dimension; for instance, a smaller size firm is more likely to be less brand orientated, as it suffers from deficient resources, thus, less willing to take risk in adopting active branding strategy. As a firm's size grows, by cumulating more resources to support their business, firms become more active in branding and adopting a more active branding strategy. Moreover, we have investigated the branding issues from the largest emerging market-China—that has not been extensively explored in the past, contributing to the contextual void in the literature.

Our B2B branding framework has enriched the industrial branding literature. The dimensions of B2B branding have long been embedded in the extant literature, but to date, only limited studies have explicitly incorporated these dimensions into a framework. For instance, Leek and Christodoulides (2011) have outlined branding benefits, brand architecture and brand communication, and Centeno et al. (2013) have drawn four distinct constructs of a brand-oriented processbrand barriers, brand orientation, brand strategy and brand distinctiveness. We take a step further by distilling the amorphous literature into a B2B branding framework. We further tested the framework with in-depth interviews. Our findings of the four types of industrial brander supplement the literature in the field of small firms' branding in emerging markets and provide directions for private firms' and SMEs' brand development.

Last, our focus on the qualitative interview from a multiindustry setting contributes to the methodological variation in the existing literature. Past research indicates that only limited studies have methodologically considered qualitative data within the context of a multi-industrial setting (Homburg et al. 2010; Keranen et al. 2012). We further combined qualitative and quantitative analysis approaches to help triangulate and complement findings.

The study yields important practical implications for manufacturers that are concerned about branding practice. Our B2B branding schema offers a strategic direction to guide the manufacturers' branding development. SME managers can undertake a preliminary analysis of their branding practice and apply the four concepts listed in the schema to conduct a self-audit practice to identify the category of B2B branders to which they belong. We suggest that the no-competencies B2B brander adopts a brand orientation and implements active corporate branding to become an awareness competencies brander. Novice and awareness competencies branders should adopt a higher degree of brand orientation, undertake a progressive approach in brand communication, and implement active corporate branding strategy in order to progress to become branders with achievement competencies. As a firm's size grows, more resources have been cumulated. For further improvement, branders with achievement competencies can aim at adopting an overall brandcentric orientation, thus becoming learning organisations in branding to enhance business performances. Our schema provides a trajectory for a progressive evolvement of B2B SME branders and proposes managerial actions for Chinese private manufacturers to develop branding strategies.

Our research also indicates that the unfavourable $\mathrm{COO}$ image is one of the major branding challenges. This findings suggests that the Chinese policymaker and industrial agency should aim at improving the overall image of 'Made in China' by upgrading the $\mathrm{COO}$ image from a low-price and mass production image to a high value-added image to help minimise the negative impact on manufacturers' branding. 
B2B firms should strategically consider some key aspects when making branding decisions. For instance, which branding architecture strategy is more appropriate for the current business? Which brand communication channel is applicable for industrial markets? We suggest that a corporate branding strategy is more applicable for B2B SMEs with limited supporting resources. Managers should be vigilant concerning the application of the corporate branding strategy, as any reckless decision will potentially harm the company's reputation.

\section{Limitations and future research}

This study is not without limitations. First, it can be challenged on what the appropriate number of interview cases is to reach data saturation. Past literature has proved that a saturation point can be reached in fewer than 12 interviews (Guest et al. 2006; Hennink et al. 2017); for example, Siu and Bao (2008) investigated manufacturer network adaptation based on 12 small manufacturer cases. The analysis evidence in our research suggested that the 17 manufacturer cases have reached a saturation point, but this might be controversial as others may demand a larger volume of qualitative data (Saunders and Townsend 2016). Therefore, we suggest that this research should be treated as a preliminary study, and future research can test the results on a large-sample scale. Moreover, our exploratory result shows some industries (i.e. electronics industry) are more active in branding than other industries in the manufacturing environment. Thus, we suggest that further research can consider investigating branding practice in a homogeneous industry - e.g. electronics industry - to generate an in-depth insight into the industry-specific branding phenomenon.

In understanding the SMEs performance in the four dimensions of brand management, the findings reveal that firms' size and business activities are intertwined with the type of impediments they encounter. For instance, a smaller firm focuses on assembly production with deficient resources is often less active in branding practice. As a firm grows, their business expands from domestic market to international market, and to differentiate their product from markets, they started actively practicing branding which they may adopt corporate branding, or product branding strategies to compete in the market. The impediments they have encountered are also changed from insufficient resources to the negative COO image and insufficient branding knowledge. Nevertheless, our finding only reveal a tentative trend and we encourage further research to explore how the size of SMEs and the nature of the business activities affect a firm's decision in undertaking different branding strategies to aid their brand development.

Our research did not find evidence in the application of region-of-origin concept to support their brand development. This may be due to the research sample is SMEs in the manufacturing industry, and region-of-origin is more prevailing in the consumer market (van Ittersum et al. 2003; Orth et al. 2005). Nevertheless, the concept of region-of-origin offers sellers a competitiveness with a consistent image of product quality, and the studies that dealing with country-of-origin and region-of-origin simultaneously help to advance the body of knowledge in B2B branding. We thus encourage the future research to explore whether the some regions in China (i.e., Shanghai, Shenzhen, Beijing) have utilised the region-of-origin concept in their brand building.

Moreover, our sample focuses on Chinese private manufacturers, excluding the state-owned enterprises (SOEs) and large companies. The majority of our sample comprises small manufacturers with fewer than or equal to 100 employees. The application of our research to large firms and SOEs is currently unknown. Future research can test our framework with large B2B firms.

Last, we select the biggest emerging market-Chinato address the research gaps. We cannot neglect the variations in the industrial structure and policy implementations between China and other emerging markets. The Chinese market is state-controlled in that the central government holds strong institutional power to steer the market direction. The distinct differences in policy, social construct and norms in emerging economies may reveal variations in industrial behaviour (Chu 2009). Thus, we suggest future researchers apply our framework in other emerging economies-for example, other BRICS (Brazil, Russia, India, China and South Africa) countries, or Central Asia-as the Chinese government recently launched the Belt and Road Initiative (Chohan 2017).

Despite these shortcomings, this study illustrates the process of deep contextualisation in Chinese B2B branding. We first undertook an extensive literature review of B2B branding and identified four possible dimensions. We further applied both qualitative and quantitative research techniques to develop a branding schema, and laid the foundation for future studies to enhance B2B branding theory in other research contexts.

Open Access This article is distributed under the terms of the Creative Commons Attribution 4.0 International License (http://creativeco mmons.org/licenses/by/4.0/), which permits unrestricted use, distribution, and reproduction in any medium, provided you give appropriate credit to the original author(s) and the source, provide a link to the Creative Commons license, and indicate if changes were made. 


\section{Appendix 1}

See Table 7.

Table 7 Semi-structured interview guide
Business backgrounds

Please introduce your company and yourself

What kind of business do you do?

Can you briefly introduce your business operation?

What does the external environment look like in your industry?

Brand orientation and brand architecture

What does the brand means to your company?

Do you have your own brand? (How many brands does your company own?)

How do you practice your branding? (what are the branding activities)

How do you value a brand in your industry? (What do they understand the industrial brand?)

Brand impediments

What affects your brand building?

Do you think your company doing well in brand building? If not, why?

What impedes building a brand in the manufacturing industry?

Brand communication

How does your company promote the brands?

What are the branding channels that your company has adopted?

What is your perceptions of branding in the future?

The interviews were part of a large project that contains a number of topics, and the interview questions that specifically relate to branding were extracted from the original project 


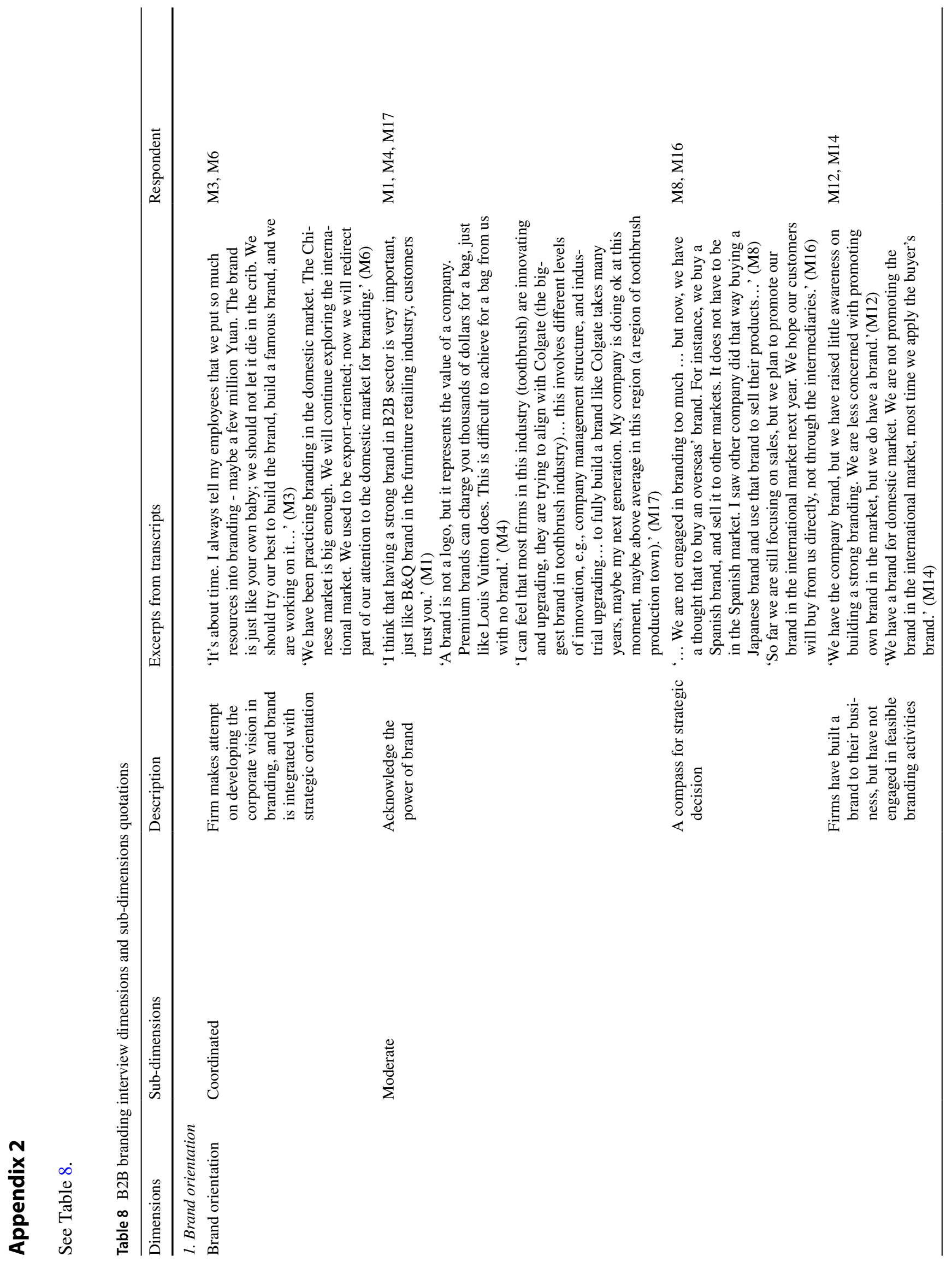




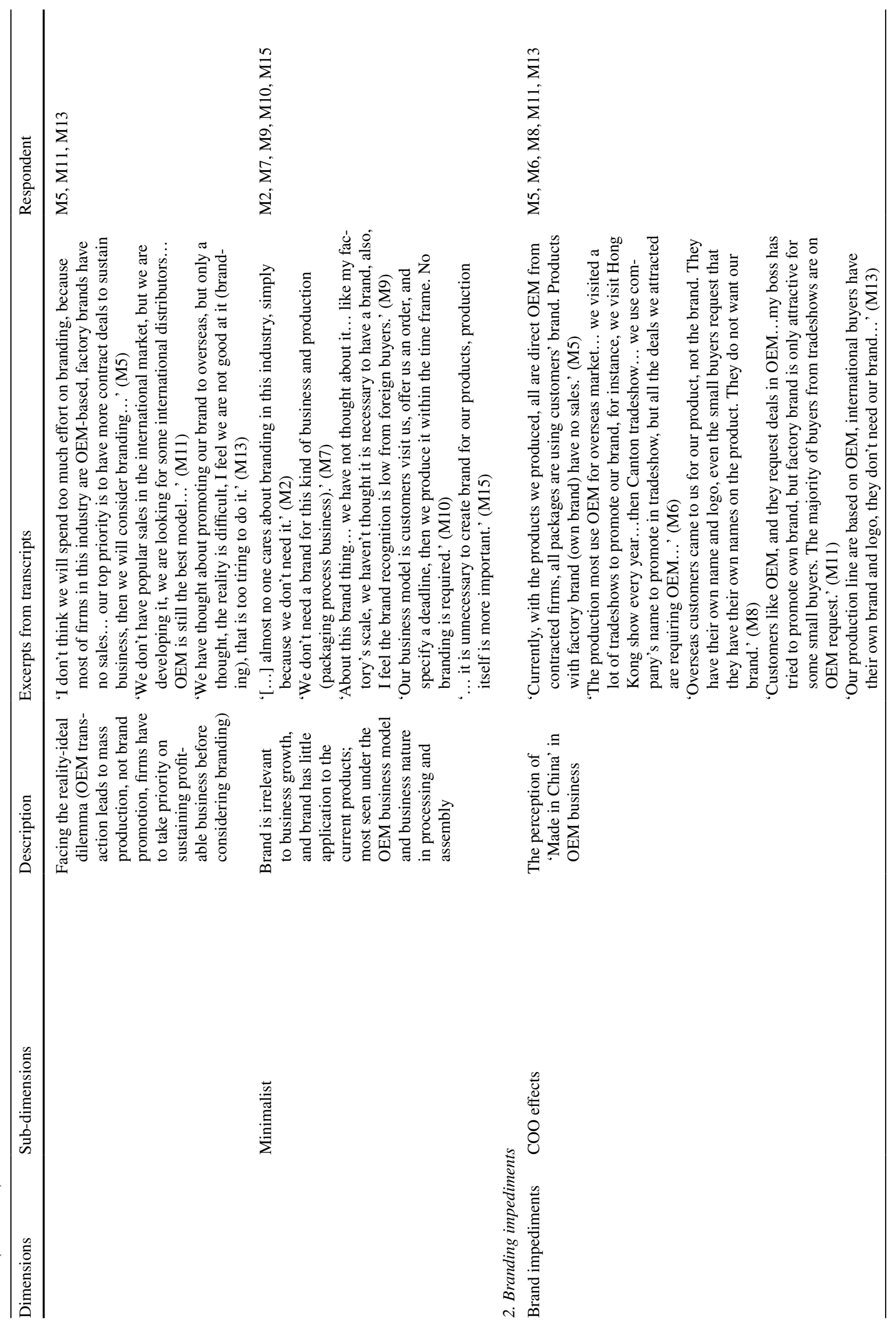

这。 


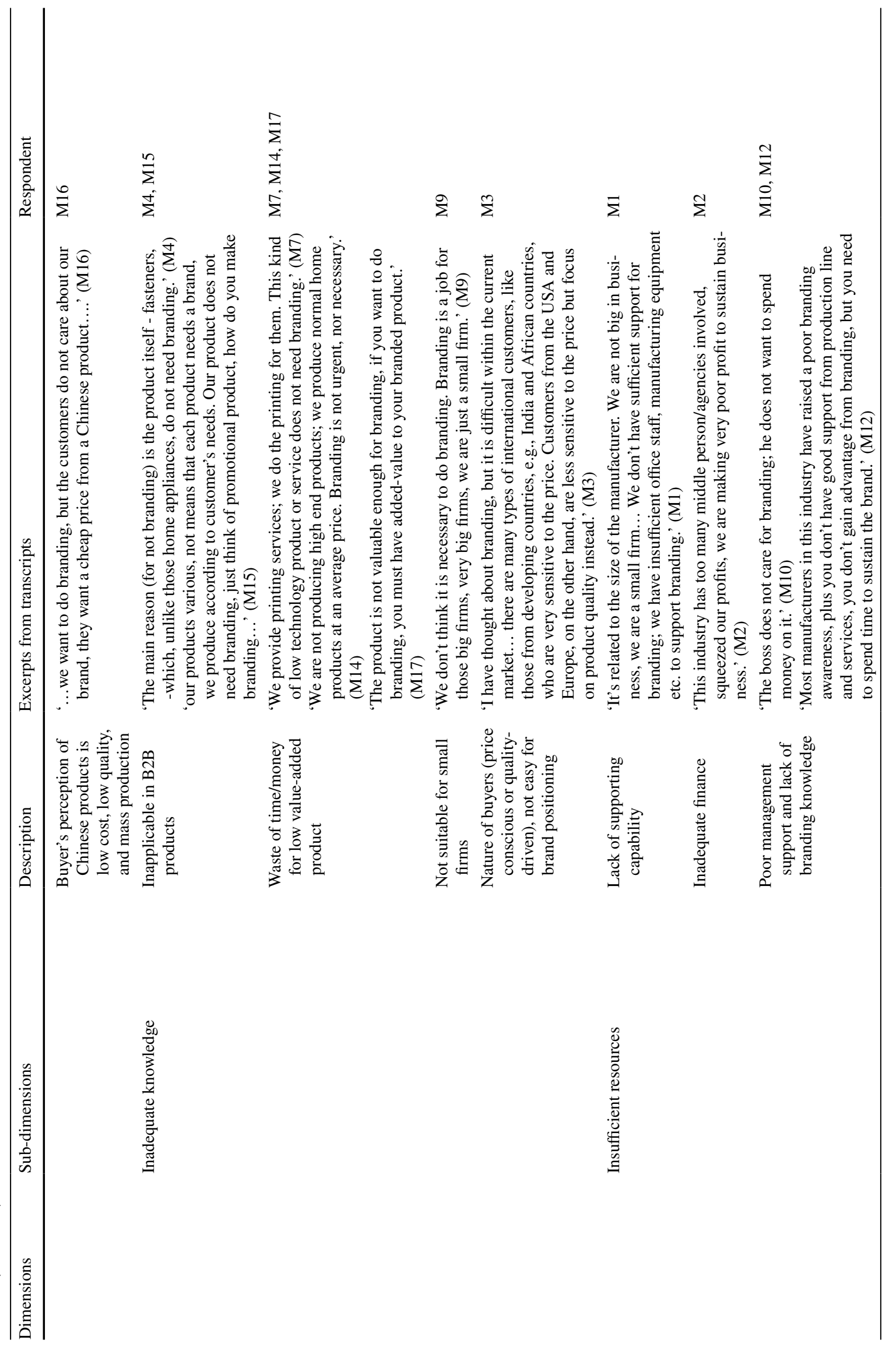




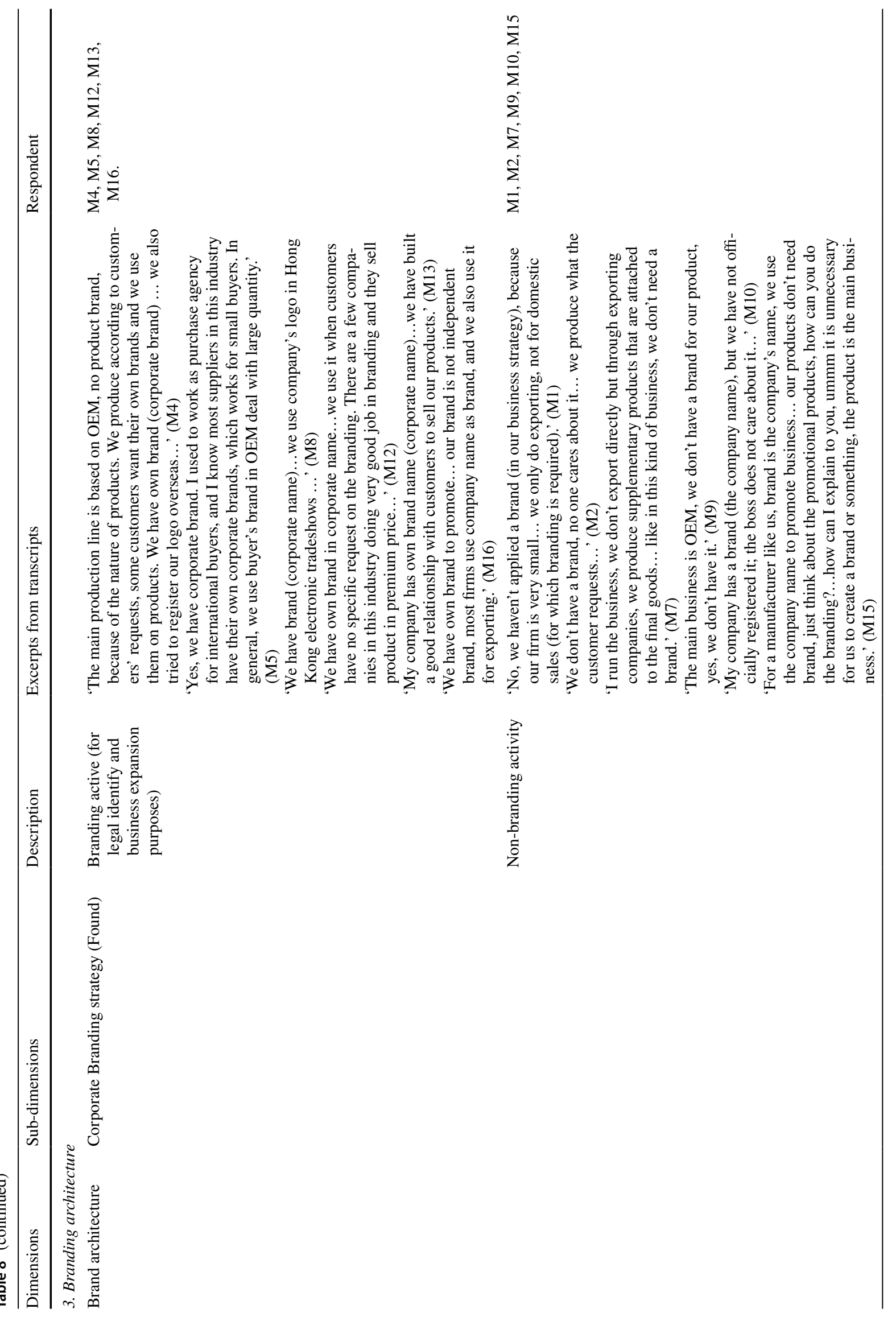

然 


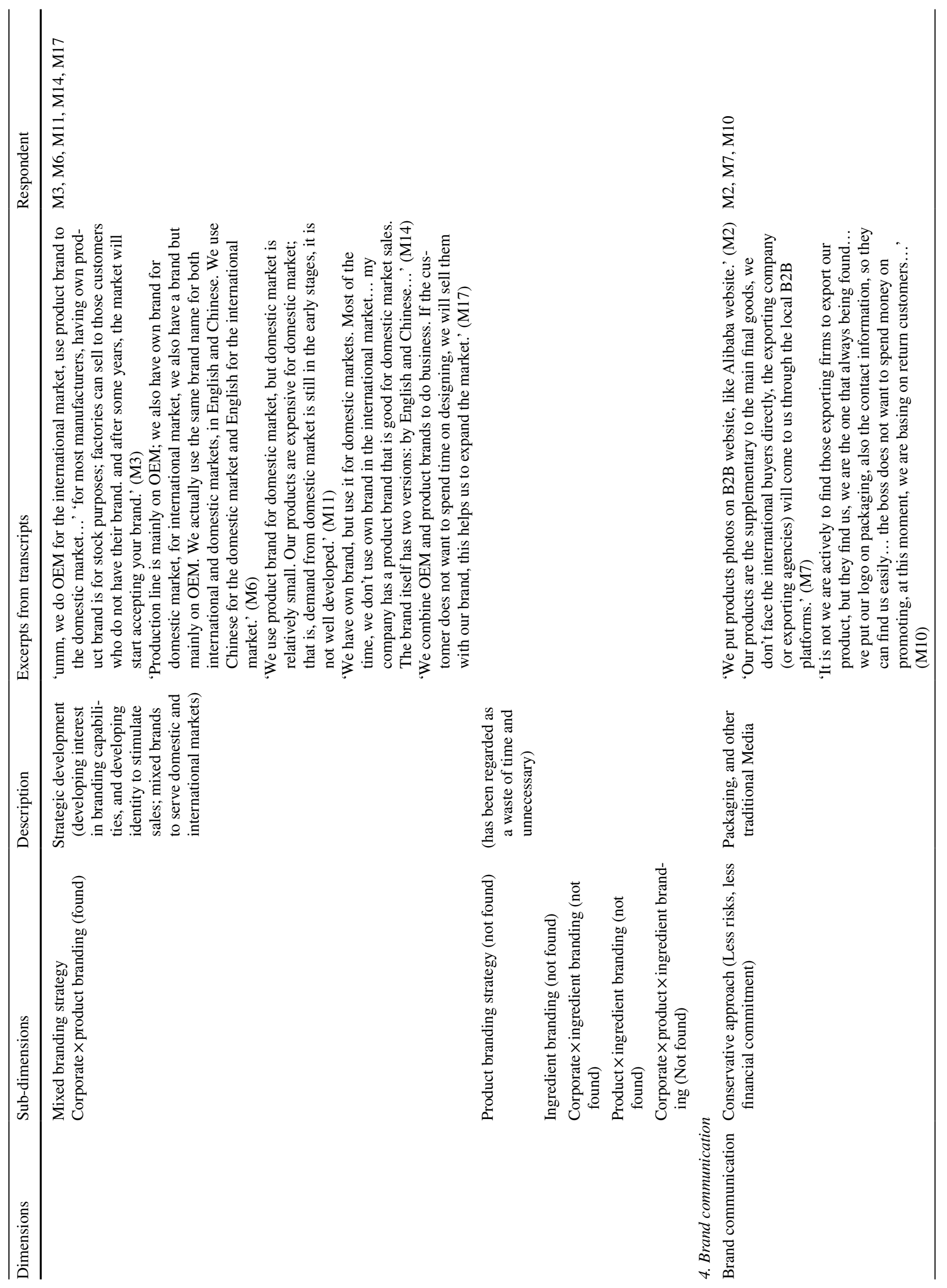




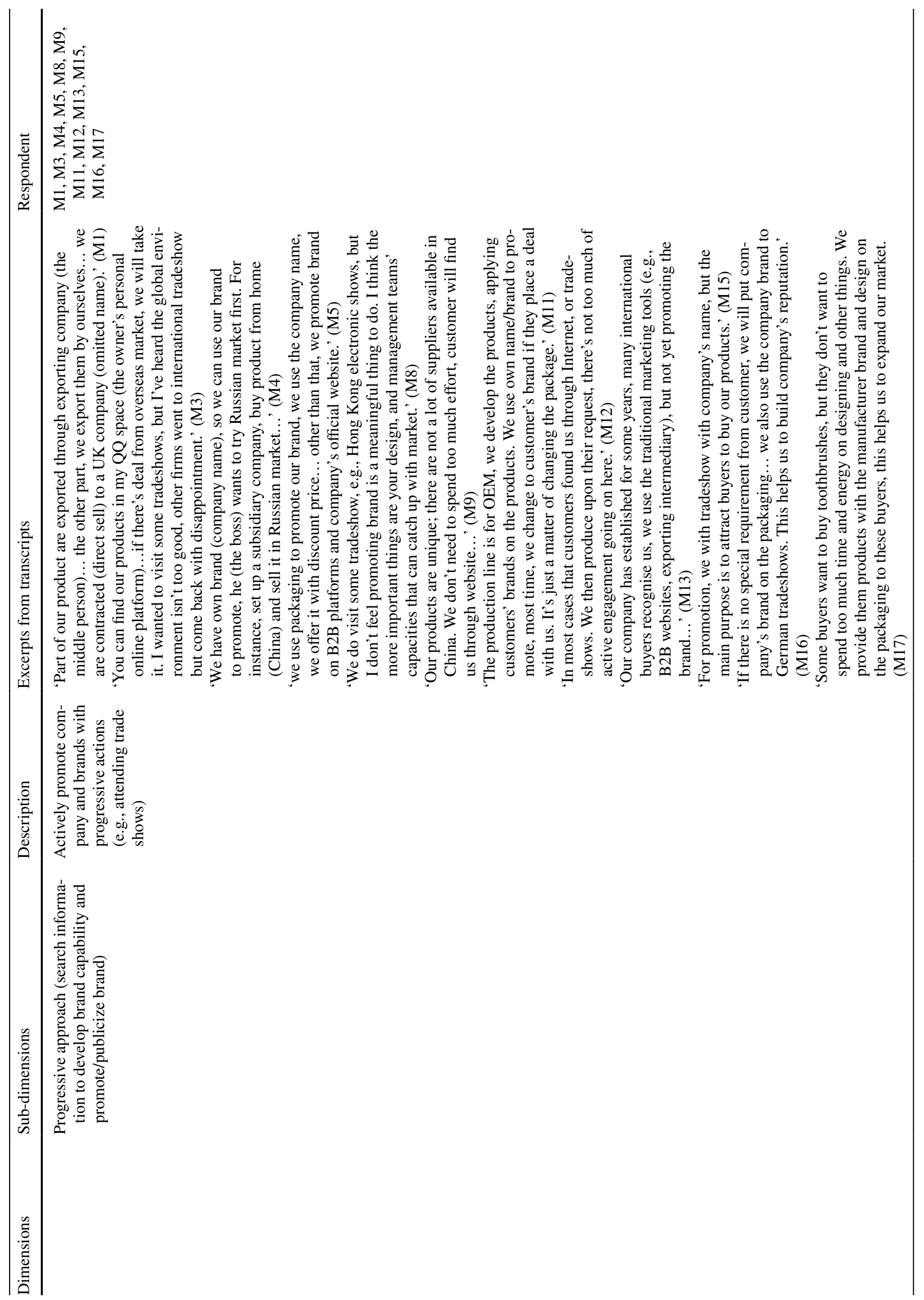

望: 


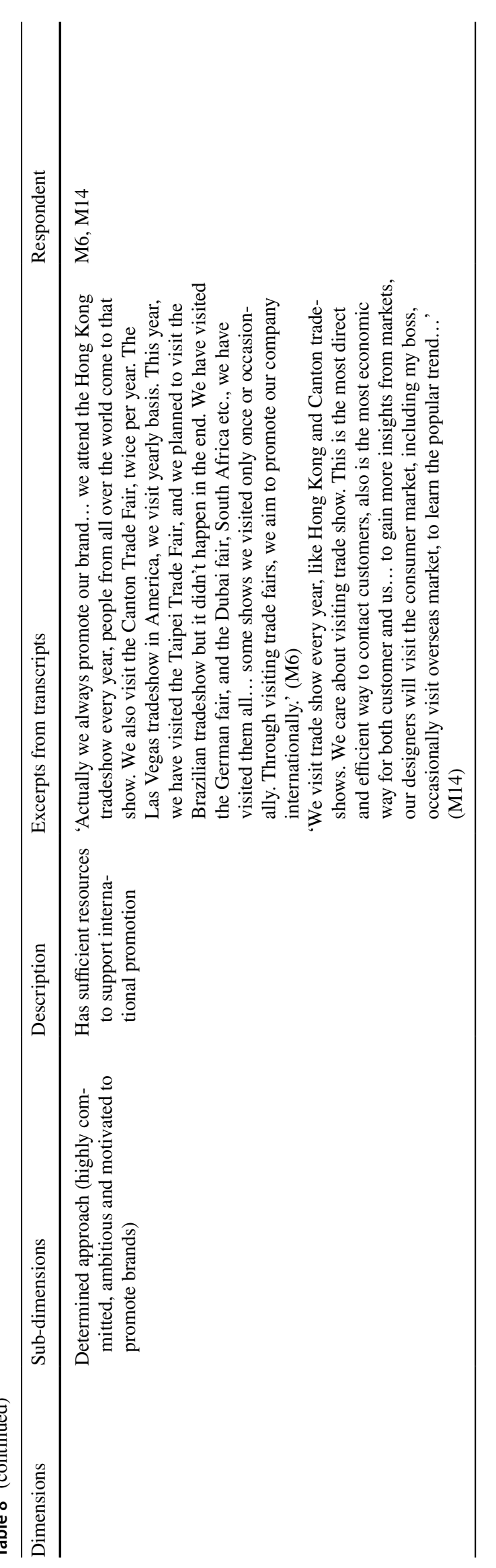




\section{Appendix 3}

See Table 9.

Table 9 Interview quotation

B2B branders Quotation

Achievement competencies 'It's about time. I always tell my employees that we put so much resources into branding - maybe a few million

(M03, M04, M14, M17) Yuan. The brand is just like your own baby; we should not let it die in the crib. We should try our best to build the brand, build a famous brand, and we are working on it...' (M3)

'A brand is not a logo, but it represents the value of a company. Premium brands can charge you thousands of dollars for a bag, just like Louis Vuitton does. This is difficult to achieve for a bag from us with no brand.' (M4)

'We visit trade shows every year, like Hong Kong and Canton tradeshows. We care about visiting trade show. This is the most direct and efficient way to contact customers; also it is the most economical way for both the customers and us... to gain more insights from markets, our designers will visit the consumer market, including my boss, occasionally visit overseas markets, to learn the popular trends...' (M14)

'Some buyers want to buy toothbrushes, but they don't want to spend too much time and energy on designing and other things. We provide them with products with the manufacturer brand and design on the packaging to these buyers, this helps us to expand our market.' (M17).

Awareness competencies (M05, M06, M08, M11, M12, M13, M16)

'I don't think we will spend too much effort on branding, because most of firms in this industry are OEM-based, factory brands have no sales... our top priority is to have more contract deals to sustain business, then we will consider branding...' (M5)

'We have been practicing branding in the domestic market. The Chinese market is big enough. We will continue exploring the international market. We used to be export-oriented; now we will redirect part of our attention to the domestic market for branding.' (M6)

'We have brand (corporate name)...we use company's logo in Hong Kong electronic tradeshows ...' (M8)

'We use product brand for domestic market, but domestic market is relatively small. Our products are expensive for domestic market; that is, demand from domestic market is still in the early stages, it is not well developed.' (M11)

'In most cases that customers found us through the Internet, or tradeshows. We then produce upon their request, there's not too much active engagement going on here.' (M12)

'We have own brand, but we have not heavily promoted it... it is necessary to promote own brand, just we don't have the time at this moment...' (M13)

'If there is no special requirement from the customer, we will put the company's brand on the packaging... we also use the company brand to sell at German tradeshows. This helps us to build the company's reputation.' (M16)

Novice competencies (M07, M09, M15)

'We don't need a brand for this kind of business and production (packaging process business).' (M7)

'The main business is OEM, we don't have a brand for our product, yes, we don't have it.' (M9)

'For promotion, we go to tradeshows with the company's name, but the main purpose is to attract buyers to buy our products.' (M15)

No competencies (M01, M02, M10)

'No, we haven't applied a brand (in our business strategy), because our firm is very small... we only do exporting, not for domestic sales (for which branding is required).' (M1)

'We don't have a brand, no one cares about it... we produce what the customer requests...' (M2)

'It is not that we are actively looking to find those exporting firms to export our product, but they find us; we are the one that is always being found... we put our logo on packaging, also on the contact information, so they can find us easily... the boss does not want to spend money on promoting, at this moment, we are basing our model on return customers...' (M10)

\section{References}

Aaker, D.A. 1991. Managing brand equity. New York: The Free Press. Ampuero, O., and N. Vila. 2006. Consumer perceptions of product packaging. Journal of Consumer Marketing 23(2): 100-112.

Anees-ur-Rehman, M., H.Y. Wong, and M. Hossain. 2016. The progression of brand orientation literature in twenty years: A systematic literature review. Journal of Brand Management 23(6): 612-630.

Anees-ur-Rehman, M., H.Y. Wong, P. Sultan, and B. Merrilees. 2018. How brand-oriented strategy affects the financial performance of B2B SMEs. Journal of Business \& Industrial Marketing 33(3): 303-315.
Aspara, J., and H. Tikanen. 2008. Significance of corporate brands for business-to-business companies. The Marketing Review 8(1): $43-60$.

Attride-Stirling, J. 2001. Thematic networks: An analytic tool for qualitative research. Qualitative Research 1(3): 385-405.

B2B International. 2016. Current trends in the world of B2B marketing. https://www.b2binternational.com/assets/b2b_marketing_surve y_2016.pdf. Accessed May 3, 2018.

Balmer, J.M.T. 2001. Corporate identity, corporate branding and corporate marketing-Seeing through the fog. European Journal of Marketing 35(3/4): 248-291.

Balmer, J.M.T. 2013. Corporate brand orientation: What is it? What of it? Journal of Brand Management 20: 723-741.

Balmer, J., and S. Greyser. 2002. Managing the multiple identities of the corporation. California Management Review 44(3): 72-87. 
Barkema, H.G., X.-P. Chen, G. George, Y. Luo, and Z.S. Tsui. 2015. West meets east: New concepts and theories. Academy of Management Journal 58(2): 460-479.

Baumgarth, C. 2010. 'Living the brand': Brand orientation in the business-to-business sector. European Journal of Marketing 44(5): 653-671.

Bendixen, M., K.A. Bukasa, and R. Abratt. 2004. Brand equity in the business-to-business market. Industrial Marketing Management 33(5): 371-380.

Bengtsson, A., and P. Servais. 2005. Co-branding on industrial markets. Industrial Marketing Management 34(7): 706-713.

Biedenbach, G., and A. Marell. 2010. The impact of customer experience on brand equity in a business-to-business services setting. Journal of Brand Management 17: 446-458.

Biemans, W.G. 2010. Business to business marketing: A value-driven approach. Berkshire: McGraw-Hill Education.

Braun, V., and V. Clarke. 2006. Using thematic analysis in psychology. Qualitative Research in Psychology 3: 77-101.

Bridson, K., and J. Evans. 2004. The secret of a fashion advantage is brand orientation. International Journal of Retail \& Distribution Management 32(8): 403-411.

Bryant, A., and K. Charmaz. 2007. The SAGE handbook of grounded theory. London: Sage.

Buil, I., L. de Chernatony, and E. Martínez. 2013. Examining the role of advertising and sales promotions in brand equity creation. Journal of Business Research 66(1): 115-122.

Burmann, C., and V. König. 2011. Does internal brand management really drive brand commitment in shared-service call centers? Journal of Brand Management 18(6): 374-393.

Candi, M., and K.B. Kahn. 2016. Functional, emotional, and social benefits of new B2B services. Industrial Marketing Management 57: $177-184$.

Cassia, F., N. Cobelli, and M. Ugolini. 2017. The effects of goodsrelated and service-related B2B brand images on customer loyalty. Journal of Business \& Industrial Marketing 32(5): 722-732.

Cavusgil, S.T. 1984. Differences among exporting firms based on their degree of internationalization. Journal of Business Research 13(2): 195-208.

Centeno, E., S. Hart, and K. Dinnie. 2013. The five phases of SME brand-building. Journal of Brand Management 20(6): 445-457.

Chen, Y.-M., Y.-F. Su, and F.-J. Lin. 2011. Country-of-origin effects and antecedents of industrial brand equity. Journal of Business Research 64(11): 1234-1238.

Child, J., and S.B. Rodrigues. 2005. The internationalization of Chinese firms: A case for theoretical extension? Management and Organization Review 1(3): 381-410.

Chohan, U.W. 2017. What is one belt one road? A surplus recycling mechanism approach. Available at SSRN: https://ssrn.com/abstr act $=2997650$. Accessed July 8, 2018.

Chu, W.-W. 2009. Can Taiwan's second movers upgrade via branding? Research Policy 38: 1054-1065.

Cretu, A.E., and R.J. Brodie. 2007. The influence of brand image and company reputation where manufacturers market to small firms: A customer value perspective. Industrial Marketing Management 36: $230-240$.

de Chernatony, L. 1999. Brand management through narrowing the gap between brand identity and brand reputation. Journal of Marketing Management 15: 1-3.

de Chernatony, L. 2009. Towards the holy grail of defining 'brand'. Marketing Theory 9(1): 101-105.

de Chernatony, L., and F.D'.O. Riley. 1998. Defining a 'brand': Beyond the literature with experts' interpretations. Journal of Marketing Management 14(5): 417-443.

Desai, K.K., and K.L. Keller. 2002. The effects of ingredient branding strategies on host brand extendibility. Journal of Marketing 66(1): 73-93.
Eisenhardt, K., and M.E. Graebner. 2007. Theory building from cases: Opportunities and challenges. Academy of Management Journal 50(1): 25-32.

Eng, T.-Y., S. Ozdemir, and G. Michelson. 2016. Brand origin and country of production congruity: Evidence from the UK and China. Journal of Business Research 69(12): 5703-5711.

Evans, J., K. Bridson, and R. Rentschler. 2012. Drivers, impediments and manifestations of brand orientation: An international museum study. European Journal of Marketing 46(11/12): $1457-1475$

Ewing, M.T., and J. Napoli. 2005. Developing and validating a multidimensional nonprofit brand orientation scale. Journal of Business Research 58(6): 841-853.

Ghosh, M., and G. John. 2009. When should original equipment manufacturers use branded component contracts with suppliers? Journal of Marketing Research 46(5): 597-611.

Gifi, A. 1990. Nonlinear multivariate analysis. Chichester: Wiley.

Glynn, M.S. 2012. Primer in B2B brand-building strategies with a reader practicum. Journal of Business Research 65: 666-675.

Gomes, M., T. Fernandes, and A. Brandão. 2016. Determinants of brand relevance in a B2B service purchasing context. Journal of Business \& Industrial Marketing 31(2): 193-204.

Gromark, J., and F. Melin. 2013. From market orientation to brand orientation in the public sector. Journal of Marketing Management 29(9-10): 1099-1123.

Guest, G., A. Bunce, and L. Johnson. 2006. How many interviews are enough? An experiment with data saturation and variability. Field Methods 18: 59-82.

Ha-Brookshire, J., and S.-H. Yoon. 2012. Country of origin factors influencing US consumers' perceived price for multinational products. Journal of Consumer Marketing 29(6): 445-454.

Hatch, M.J., and M. Schultz. 2003. Bringing the corporate into corporate branding. European Journal of Marketing 37(7/8): 1041-1064.

Hennink, M.M., B.N. Kaiser, and V.C. Marconi. 2017. Code saturation versus meaning saturation: How many interviews are enough? Qualitative Health Research 27(4): 591-608.

Hirvonen, S., and T. Laukkanen. 2014. Brand orientation in small firms: An empirical test of the impact on brand performance. Journal of Strategic Marketing 22(1): 41-58.

Hirvonen, S., T. Laukkanen, and J. Salo. 2016. Does brand orientation help B2B SMEs in gaining business growth? Journal of Business \& Industrial Marketing 31(4): 472-487.

Holbrook, A.L., M.C. Green, and J.A. Krosnick. 2003. Telephone versus face-to-face interviewing of national probability samples with long questionnaires: Comparisons of respondent satisfying and social desirability response bias. Public Opinion Quarterly 67(1): 79-125.

Homburg, C., M. Klarmann, and J. Schmitt. 2010. Brand awareness in business markets: When is it related to firm performance? International Journal of Research in Marketing 27(3): 201-212.

Huang, Y.-T., and Y.-T. Tsai. 2013. Antecedents and consequences of brand-oriented companies. European Journal of Marketing 47(11/12): 2020-2041.

Hutt, M., and T.W. Speh. 2001. Business marketing management: A strategic view of industrial and organizational markets. Mason: South-Western Cengage Learning.

Interbrand. 2016. Best global brands. http://interbrand.com/best-brand s/best-global-brands/2016/ranking/. Accessed May 20, 2018.

Jarvinen, J., A. Tollinen, H. Karjaluoto, and C. Jayawardhena. 2012. Digital and social media marketing usage in B2B industrial section. Journal of Marketing Management 22(2): 107-117.

Karjaluoto, H., N. Mustonen, and P. Ulkuniemi. 2015. The role of digital channels in industrial marketing communications. Journal of Business \& Industrial Marketing 30(6): 703-710. 
Kassarjian, H.H. 1977. Content analysis in consumer research. Journal of Consumer Research 4(2): 8-18.

Kay, M.J. 2006. Strong brands and corporate brands. European Journal of Marketing 40(7/8): 742-760.

Keller, K.L. 1993. Conceptualizing, measuring, and managing customer-based brand equity. Journal of Marketing 57(1): 1-22.

Keller, K.L. 2013. Strategic brand management: Building, measuring, and managing brand equity, 4th ed. Harlow: Pearson.

Keller, K.L., and P. Kotler. 2012. Branding in B2B firms. In Handbook of business-to-business marketing, ed. L. Gary and G. Rajdeep, 208-225. Cheltenham: Edward Elgar.

Keranen, J., K.A. Piirainen, and R.T. Salminen. 2012. Systematic review on B2B branding: Research issues and avenues for future research. Journal of Product \& Brand Management 21(6): 404-417.

Kerr, C., A. Nixon, and D. Wild. 2010. Assessing and demonstrating data saturation in qualitative inquiry supporting patient-reported outcome research. Expert Review of Pharmacoeconomics \& Outcomes Research 10: 269-281.

Khan, H., and D. Ede. 2009. How do not-for-profit SMEs attempt to develop a strong brand in an increasingly saturated market? Journal of Small Business and Enterprise Development 16(2): 335-354.

King, C., K.K.F. So, and D. Grace. 2013. The influence of service brand orientation on hotel employees' attitude and behaviours in China. International Journal of Hospitality Management 34: 172-180.

Knox, S. 2004. Positioning and branding your organisation. Journal of Product \& Brand Management 13(2): 105-115.

Kollmann, T., and C. Suckow. 2007. The corporate brand naming process in the net economy. Qualitative Market Research: An International Journal 10(4): 349-361.

Kotler, P., and W. Pfoertsch. 2006. B2B brand management. Berlin: Springer.

Kotler, P., and W. Pfoertsch. 2010. Ingredient branding: Making the invisible visible. Heidelberg: Springer.

Krake, F.B.J.M. 2005. Successful brand management in SMEs: A new theory and practical hints. Journal of Product \& Brand Management 14(4): 228-238.

Kuhn, K.L., F. Alpert, and N.K.L. Pope. 2008. An application of Keller's brand equity model in a B2B context. Qualitative Market Research: An International Journal 11(1): 40-58.

Lacka, E., and A. Chong. 2016. Usability perspective on social media sites' adoption in the B2B context. Industrial Marketing Management 54: 80-91.

Lance, C.E., M.M. Butts, and L.C. Michels. 2006. The sources of four commonly reported cutoff criteria: What did they really say? Organizational Research Methods 9(2): 202-220.

Lee, W.J., A. O'Cass, and P. Sok. 2017. Unpacking brand management superiority: Examining the interplay of brand management capability, brand orientation and formalisation. European Journal of Marketing 51(1): 177-199.

Leek, S., and G. Christodoulides. 2011. A literature review and future agenda for B2B branding: Challenges of branding in a B2B context. Industrial Marketing Management 40: 830-837.

Leek, S., and G. Christodoulides. 2012. A framework of brand value in B2B markets: The contributing role of functional and emotional components. Industrial Marketing Management 41(1): 106-114.

Liang, X., L. Wang, and Z. Cui. 2014. Chinese private firms and internationalization: Effects of family involvement in management and family ownership. Family Business Review 27(2): 126-141.

Lilien, G.L., R. Grewal, D. Bowman, M. Ding, A. Griffin, V. Kumar, D. Narayandas, R. Peres, R. Srinivasan, and Q. Wang. 2010. Calculating, creating, and claiming value in business markets: Status and research agenda. Marketing Letters 21(3): 287-299.
Lin, C.-W., K.-Y. Wang, S.-H. Change, and J.-A. Lin. 2019. Investigating the development of brand loyalty in brand communities from a positive psychology perspective. Journal of Business Research 99: 446-455.

Linting, M., J.J. Meulman, P.J.F. Groenen, and A.J. Van Der Kooij. 2007. Nonlinear principal components analysis: Introduction and application. Psychological Methods 12: 336-358.

Linting, M., and A. van der Kooij. 2012. Nonlinear principal components analysis with CATPCA: A tutorial. Journal of Personality Assessment 94(1): 12-25.

Liu, H., and K. Li. 2002. Strategic implications of emerging Chinese multinationals: The Haier case study. European Management Journal 20(6): 699-706.

Louro, M., and P. Cunha. 2001. Brand management paradigm. Journal of Marketing Management 17: 849-876.

Malaska, M., S. Saraniemi, and J. Tahtinen. 2011. Network actors' participation in B2B SME branding. Industrial Marketing Management 40: 1144-1152.

Man, T.W.Y., and T. Lau. 2000. Entrepreneurial competencies of SME owner/managers in the Hong Kong services sector: A qualitative analysis. Journal of Enterprising Culture 8(3): 235-254.

Marquardt, A.J. 2013. Relationship quality as a resource to build industrial brand equity when products are uncertain and future-based. Industrial Marketing Management 42(8): 1386-1397.

Mayer, K.J., D. Somaya, and I.O. Williamson. 2012. Firm-specific, industry-specific, and occupational human capital and the sourcing of knowledge work. Organization Science 23(5): 1311-1329.

Merrilees, B., and D. Miller. 2008. Principles of corporate rebranding. European Journal of Marketing 42(5/6): 537-552.

Meulman, J.J., A.J. Van Der Kooij, and W.J. Heiser. 2004. Principal components analysis with nonlinear optimal scaling transformations for ordinal and nominal data. In The Sage handbook of quantitative methodology for the social sciences, ed. D. Kaplan, 49-70. California: Sage.

Michaelidou, N., N.T. Siamagka, and G. Christodoulides. 2011. Usage, barriers and measurement of social media marketing: An exploratory investigation of small and medium B2B brands. Industrial Marketing Management 40: 1153-1159.

Michailidis, G., and J. de Leeuw. 1998. The Gifi system of descriptive multivariate analysis. Statistical Science 13(4): 307-336.

Michell, P., J. King, and J. Reast. 2001. Brand values related to industrial products. Industrial Marketing Management 30: 415-425.

Miles, M.B., and A.M. Huberman. 1994. Qualitative data analysis: An expanded sourcebook, 2nd ed. London: Sage.

Ministry of Commerce of the People's Republic of China. 2016. Regular press conference of the Ministry of Commerce (December 9, 2016). Beijing, China. http://english.mofcom.gov.cn/article/ pressconferenceinyears/2016/201612/20161202192275.shtml. Accessed November 20, 2017.

Mitchell, R., K. Hutchinson, and S. Bishop. 2012. Interpretation of the retail brand: An SME perspective. International Journal of Retail and Distribution Management 40(2): 157-175.

Mitchell, R., K. Hutchinson, B. Quinn, and A. Gilmore. 2015. A framework for SME retail branding. Journal of Marketing Management 31: 17-18.

Moon, H., and D.E. Sprott. 2016. Ingredient branding for a luxury brand: The role of brand and product fit. Journal of Business Research 69(12): 5768-5774.

Mudambi, S.M., P. Doyle, and V. Wong. 1997. An exploration of branding in industrial markets. Industrial Marketing Management 26: 433-446.

Muelman, J.J., and W.J. Heiser. 2012. IBM SPSS categories 21. New York: IBM Corporation.

Namey, E., G. Guest, K. McKenna, and M. Chen. 2016. Evaluating bang for the buck: A cost-effectiveness comparison between 
individual interviews and focus groups based on thematic saturation levels. American Journal of Evaluation 37: 425-440.

Norris, D.G. 1992. Ingredient branding: A strategy option with multiple beneficiaries. Journal of Consumer Marketing 9(3): 19-31.

Nyadzayo, M.W., M.J. Matanda, and M.T. Ewing. 2011. Brand relationships and brand equity in franchising. Industrial Marketing Management 40: 1103-1115.

Nyadzayoa, M.W., M.J. Matanda, and R. Rajaguru. 2018. The determinants of franchise brand loyalty in B2B markets: An emerging market perspective. Journal of Business Research 86: 434-445.

Odekerken-Schröder, G., T. Hennig-Thurau, and A.B. Knaevelsrud. 2010. Exploring the post-termination stage of consumer-brand relationships: An empirical investigation of the premium car market. Journal of Retailing 86: 372-385.

Ohnemus, L. 2009. B2B branding: A financial burden for shareholders? Business Horizons 52: 159-166.

Ojasalo, J., S. Natti, and R. Olkkonen. 2008. Brand building in software SMEs: An empirical study. Journal of Product and Brand Management 17: 92-107.

Orth, U.R., M.C. Wolf, and T.H. Dodd. 2005. Dimensions of wine region equity and their impact on consumer preferences. Journal of Product \& Brand Management 14(2): 88-97.

Österle, B., M.M. Kuhn, and J. Henseler. 2018. Brand worlds: Introducing experiential marketing to B2B branding. Industrial Marketing Management 72: 71-98.

Prior, D.D. 2013. Supplier representative activities and customer perceived value in complex industrial solutions. Industrial Marketing Management 42(8): 1192-1201.

Radighieri, J.P., B.J. Mariadoss, Y. Grégoire, and J.L. Johnson. 2014. Ingredient branding and feedback effects: The impact of product outcomes, initial parent brand strength asymmetry, and parent brand role. Marketing Letters 25(2): 123-138.

Raymond, L., L. Cadieux, and J. St-Pierre. 2012. Implication of the SME owner-manager's business venturing mode: Comparing founders, acquirers and successors. Journal of Enterprising Culture 20(1): 57-81.

Richter, M. 2007. Markenbedeutung und-management im Industrieguterbereich. Wiesbaden: DUV.

Ritchie, J., and J. Lewis. 2003. Qualitative research practice: A guide for social science students and researchers. London: SAGE.

Roberts, J., and B. Merrilees. 2007. Multiple roles of brands in business-to-business services. Journal of Business \& Industrial Marketing 22(6): 410-417.

Saunders, M.N.K., and K. Townsend. 2016. Reporting and justifying the number of interview participants in organisation and workplace research. British Journal of Management 27: 836-852.

Sekaran, U., and R. Bougie. 2010. Research method for business-a skill building approach. West Sussex: Wiley.

Seyedghorban, Z., M.J. Matanda, and P. LaPlaca. 2016. Advancing theory and knowledge in the business-to-business branding literature. Journal of Business Research 69(8): 2664-2677.

Sharma, A. 2002. Trends in internet-based business-to-business marketing. Industrial Marketing Management 31: 77-84.

Sharma, A. 2016. What personal selling and sales management recommendations from developed markets are relevant in emerging markets? Journal of Personal Selling \& Sales Management 36(2): 89-104.

Sheth, J.N. 2011. Impact of emerging markets on marketing: Rethinking existing perspectives and practices. Journal of Marketing 75(4): 166-182.

Sheth, J.N., and M. Sinha. 2015. B2B branding in emerging markets: A sustainability perspective. Industrial Marketing Management 51: 79-88.

Simoes, C., J. Singh, and M.G. Perin. 2015. Corporate brand expressions in business-to-business companies' websites: Evidence from Brazil and India. Industrial Marketing Management 51: $59-68$.

Siu, W.-S. 2005. An institutional analysis of marketing practices of small and medium-sized enterprises (SMEs) in China, Hong Kong and Taiwan. Entrepreneurship \& Regional Development 17(1): 65-88.

Siu, W.-S., and Q. Bao. 2008. Network strategies of small Chinese high-technology firms: A qualitative study. Journal of Product Innovation Management 25: 79-102.

Spence, M., and L.H. Essoussi. 2010. SME brand building and management: An exploratory study. European Journal of Marketing 44(7/8): 1037-1054.

Steimer, S. 2016. Trade shows still the best bet for B-to-B marketers. https://www.ama.org/publications/eNewsletters/B2BMarketing/ Pages/dont-take-trade-shows-for-granted-btob-marketing.aspx. Accessed January 20, 2017.

Strebinger, A. 2014. Rethinking brand architecture: A study on industry, company- and product-level drivers of branding strategy. European Journal of Marketing 48(9/10): 1782-1804.

Tarnovskaya, V., and G. Biedenbach. 2016. Multiple stakeholders and B2B branding in emerging markets. Qualitative Market Research: An International Journal 9(3): 287-309.

Thode, S.F., and J.M. Maskulka. 1998. Place-based marketing strategies, brand equity and vineyard valuation. Journal of Product \& Brand Management 7(5): 379-399.

Tsui, A.S. 2007. From homogenization to pluralism: International management research in the academy and beyond. Academy of Management Journal 50(6): 1353-1364.

Underwood, R.L., N. Klein, and R. Burke. 2001. Packaging communication: Attentional effects of product imagery. Journal of Product and Brand Management 10(7): 403-422.

Urde, M. 1999. Brand orientation: A mindset for building brands into strategic resources. Journal of Marketing Management 15: 117-133.

Urde, M. 2003. Core value-based corporate brand building. European Journal of Marketing 37(7/8): 1017-1040.

Urde, M., C. Baumgarth, and B. Merrilees. 2013. Brand orientation and market orientation-From alternatives to synergy. Journal of Business Research 66: 13-20.

Vaidyanathan, R., and P. Aggarwal. 2000. Strategic brand alliances: Implications of ingredient branding for national and private label brands. The Journal of Product and Brand Management 9(4): 214-228.

Vallaster, C., and A. Lindgreen. 2011. Corporate brand strategy formation: Brand actors and the situational context for a business-to-business brand. Industrial Marketing Management 40: $1133-1143$.

Van Ittersum, K., M.J.J.M. Candel, and M.T.G. Meulenberg. 2003. The influence of the image of a product's region of origin on product evaluation. Journal of Business Research 56(3): 215-226.

Van Rompay, T.J.L., M.L. Fransen, and B.G.D. Borgelink. 2014. Light as a feather: Effects of packaging imagery on sensory product impressions and brand evaluation. Marketing Letter 25: 397-407.

Viardot, E. 2017. Branding in B2B: The value of consumer goods brands in industrial markets. Journal of Business \& Industrial Marketing 32(3): 337-346.

Wang, C.L., J. He, and B.R. Barnes. 2017. Brand management and consumer experience in emerging markets: Directions for future research. International Marketing Review 34(4): 458-462.

Wang, C.L., D. Li, B.R. Barnes, and J. Ahn. 2012. Country image, product image and consumer purchase intention: Evidence from an emerging economy. International Business Review 21: $1041-1051$.

Ward, S., and F.E. Webster Jr. 1991. Organizational buying behaviour. In Handbook of consumer behaviour, ed. T. Robertson and $\mathrm{H}$. Kassarjian, 419-458. Upper Saddle River: Prentice Hall. 
Ward-King, J., I.L. Cohen, H. Penning, and J.J.A. Holden. 2010. Brief report: Telephone administration of the autism diagnostic interview-Revised: Reliability and suitability for use in research. Journal of Autism and Developmental Disorders 40(10): $1285-1290$.

Webster, F.E., and K.L. Keller. 2004. A roadmap for branding in industrial markets. Journal of Brand Management 11(5): 388-402.

Wong, H.Y., and B. Merrilees. 2005. A brand orientation typology for SMEs: A case research approach. Journal of Product \& Brand Management 14(3): 155-162.

Wong, H.Y., and B. Merrilees. 2008. The performance benefits of being brand-orientated. Journal of Product \& Brand Management 17(6): 372-383.

Yanamandram, V., and L. White. 2006. Switching barriers in businessto-business services: A qualitative study. Journal of Services Marketing 17(2): 158-192.

Zhang, J., Y. Jiang, R. Shabbir, and M. Zhu. 2016. How brand orientation impacts B2B service brand equity? An empirical study among Chinese firms. Journal of Business \& Industrial Marketing 31(1): 83-98.

Zhu, Y., X. Wittmann, and M.W. Peng. 2012. Institution-based barriers to innovation in SMEs in China. Asia Pacific Journal of Management 29: 1131-1142.
Publisher's Note Springer Nature remains neutral with regard to jurisdictional claims in published maps and institutional affiliations.

Dr. Fenfang Lin is a lecturer in Marketing at the University of Southampton, M.Sc. Digital Marketing Programme Coordinator. She holds a Ph.D. in Marketing from the University of Edinburgh with a number of years working experience in different industries. Her research interests lie in B2B SMEs branding, strategic marketing, and marketing capability development.

Dr. Wai-Sum Siu is a Professor in marketing at Hong Kong Baptist University. His research focuses on small firm marketing. He has published in Journal of World Business, Journal of Product Innovation Management, etc. He has been a member of editorial board for the European Journal of Marketing, and the International Journal of Entrepreneurship and Innovation. 